\title{
VOC reactivity in central California: comparing an air quality model to ground-based measurements
}

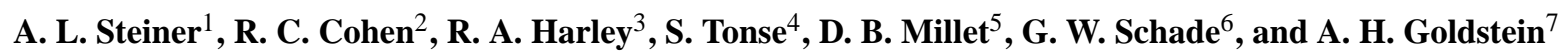 \\ ${ }^{1}$ Department of Atmospheric, Oceanic and Space Sciences, University of Michigan, Ann Arbor, MI, USA \\ ${ }^{2}$ Department of Chemistry, University of California, Berkeley, CA, USA \\ ${ }^{3}$ Department of Civil and Environmental Engineering, University of California, Berkeley, CA, USA \\ ${ }^{4}$ Lawrence Berkeley National Laboratory, Berkeley, CA, USA \\ ${ }^{5}$ Department of Earth and Planetary Sciences, Harvard University, Cambridge, MA, USA \\ ${ }^{6}$ Department of Atmospheric Sciences, Texas A\&M University, College Station, TX, USA \\ ${ }^{7}$ Department of Environmental Science, Policy and Management, University of California, Berkeley, CA, USA
}

Received: 16 August 2007 - Published in Atmos. Chem. Phys. Discuss.: 7 September 2007

Revised: 6 December 2007 - Accepted: 20 December 2007 - Published: 29 January 2008

\begin{abstract}
Volatile organic compound (VOC) reactivity in central California is examined using a photochemical air quality model (the Community Multiscale Air Quality model; CMAQ) and ground-based measurements to evaluate the contribution of VOC to photochemical activity. We classify VOC into four categories: anthropogenic, biogenic, aldehyde, and other oxygenated VOC. Anthropogenic and biogenic VOC consist of primary emissions, while aldehydes and other oxygenated VOC include both primary anthropogenic emissions and secondary products from primary VOC oxidation. To evaluate the model treatment of VOC chemistry, we compare calculated and modeled $\mathrm{OH}$ and VOC reactivities using the following metrics: 1) cumulative distribution functions of $\mathrm{NO}_{\mathrm{x}}$ concentration and VOC reactivity $\left.\left(\mathrm{R}_{\mathrm{OH}, \mathrm{VOC}}\right), 2\right)$ the relationship between $\mathrm{R}_{\mathrm{OH}, \mathrm{VOC}}$ and $\mathrm{NO}_{\mathrm{x}}$, $3)$ total $\mathrm{OH}$ reactivity $\left(\mathrm{R}_{\mathrm{OH}, \text { total }}\right)$ and speciated contributions, and 4) the relationship between speciated $\mathrm{R}_{\mathrm{OH}, \mathrm{VOC}}$ and $\mathrm{NO}_{\mathrm{x}}$. We find that the model predicts $\mathrm{R}_{\mathrm{OH} \text {,total }}$ to within $25-40 \%$ at three sites representing urban (Sacramento), suburban (Granite Bay) and rural (Blodgett Forest) chemistry. However in the urban area of Fresno, the model under predicts $\mathrm{NO}_{\mathrm{x}}$ and VOC emissions by a factor of 2-3. At all locations the model is consistent with observations of the relative contributions of total VOC. In urban areas, anthropogenic and biogenic $\mathrm{R}_{\mathrm{OH}, \mathrm{VOC}}$ are predicted fairly well over a range of $\mathrm{NO}_{\mathrm{x}}$ conditions. In suburban and rural locations, anthropogenic and other oxygenated $\mathrm{R}_{\mathrm{OH}, \mathrm{VOC}}$ relationships are reproduced, but calculated biogenic and aldehyde $\mathrm{R}_{\mathrm{OH}, \mathrm{VOC}}$ are often poorly characterized by measurements, making evaluation of the model with available data unreliable. In central California,
\end{abstract}

Correspondence to: A. L. Steiner

(alsteiner@umich.edu)
$30-50 \%$ of the modeled urban VOC reactivity is due to aldehydes and other oxygenated species, and the total oxygenated $\mathrm{R}_{\mathrm{OH}, \mathrm{VOC}}$ is nearly equivalent to anthropogenic VOC reactivity. In rural vegetated regions, biogenic and aldehyde reactivity dominates. This indicates that more attention needs to be paid to the accuracy of models and measurements of both primary emissions of oxygenated VOC and secondary production of oxygenates, especially formaldehyde and other aldehydes, and that a more comprehensive set of oxygenated VOC measurements is required to include all of the important contributions to atmospheric reactivity.

\section{Introduction}

Atmospheric concentrations of volatile organic compounds (VOC) depend on primary anthropogenic and biogenic emissions, chemical formation and loss in the atmosphere (due to gaseous, aqueous and heterogeneous chemical reactions), and removal from the atmosphere due to dry and wet deposition. A wide suite of VOC with varying chemical properties is present in the atmosphere, and the chemical structures of these compounds affect reactivity (Atkinson, 2000). Once in the atmosphere, VOC oxidation leads to the formation of tropospheric ozone when in combination with sufficient concentrations of nitrogen oxides $\left(\mathrm{NO}_{\mathrm{x}}=\mathrm{NO}+\mathrm{NO}_{2}\right)$ and sunlight. VOC oxidation also leads to the formation of secondary organic aerosol via gas-to-particle conversion (e.g., Odum et al., 1997), aqueous phase chemistry (e.g., Ervens et al., 2004), and/or oligomerization (e.g., Kalberer et al., 2004).

Published by Copernicus Publications on behalf of the European Geosciences Union. 
Reducing anthropogenic VOC and/or $\mathrm{NO}_{\mathrm{x}}$ precursor emissions has been the main method of controlling ozone in the United States over the past several decades (National Research Council, 1991). In some regions, such as the Los Angeles area in southern California, control of anthropogenic VOC from automobiles and industrial processes has proven effective at reducing ozone exceedances over the past three decades, indicating that VOC were the limiting factor in ozone production in this region (Milford et al., 1989; Martien and Harley, 2006). In other regions with high emissions of biogenic VOC, $\mathrm{NO}_{\mathrm{x}}$ control has been more efficient at reducing ozone (Trainer et al., 1988; Sillman et al., 1990; Cardelino and Chameides, 1990; Han et al., 2005). In central California, differences between weekday and weekend ozone concentrations indicate that ozone production in urban regions are $\mathrm{NO}_{\mathrm{x}}$-saturated while more remote areas such as the southern San Joaquin Valley and the Sierra Nevada are more $\mathrm{NO}_{\mathrm{x}}$-sensitive (Blanchard and Fairley, 2001; Marr and Harley, 2002; Murphy et al., 2006a, b).

Certain VOC such as alkenes are more reactive than alkanes and, in the hours immediately after emission, they can contribute more to ozone formation per unit mass. As a result, VOC have been ranked according to their ozone formation potential and incremental contributions to ozone production (e.g., Carter, 1994). One element of the overall control strategy has been to use modeling studies to identify and reduce VOC with high ozone formation potential (Russell et al., 1995; Avery, 2006).

This approach requires an assessment of regional VOC reactivity and applicable control strategies, which are often performed using air quality models. Recent studies have used ground-based VOC measurements to assess VOC reactivity and validate emission inventories. These results vary by location, but studies suggest that urban alkanes and alkenes tend to be under estimated by current inventories, while aromatics such as toluene tend to be over estimated (Jiang and Fast, 2004; Choi et al., 2006; Velasco et al., 2007; Warnecke et al., 2007). This suggests that proposed control strategies targeting specific VOC species might be less effective than predicted due to errors in emissions inventories.

In our prior analysis of climate effects on ozone in California (Steiner et al., 2006), we used ground-based measurements of ozone concentrations to evaluate model performance and found that the model reproduced the spatial distributions and daily maximum ozone concentrations in the San Joaquin Valley and in the eastern portion of the San Francisco Bay area. Here, we utilize ground-based $\mathrm{VOC}$ and $\mathrm{NO}_{\mathrm{x}}$ measurements to develop metrics to evaluate the representation of VOC reactivity in a regional chemical transport model. We do this by comparing calculated and modeled 1) cumulative distribution functions of $\mathrm{NO}_{\mathrm{x}}$ and $\mathrm{R}_{\mathrm{OH}, \mathrm{VOC}}, 2$ ) the relationship between $\mathrm{ROH}_{\mathrm{O}, \mathrm{VOC}}$ and $\mathrm{NO}_{\mathrm{x}}, 3$ ) speciated contribu-

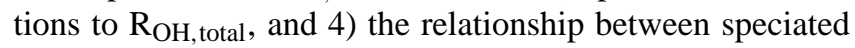
$\mathrm{R}_{\mathrm{OH}, \mathrm{VOC}}$ and $\mathrm{NO}_{\mathrm{x}}$. Additionally, we provide a discussion of the present day and future VOC component of ozone produc- tion in order to understand more fully the chemical factors that may change under future climate and guide the development of air quality control strategies.

\section{Methods}

\subsection{Model simulations}

We investigate VOC reactivity for an episodic air quality simulation in central California using the Community Multiscale Air Quality model (CMAQ, Byun and Ching, 1999). We compare two five-day simulations, where the first simulation represents an ozone episode during the summer of 2000 (29/7/2000-3/8/2000). During this time period, stagnant conditions and warm temperatures led to high ozone concentrations in the southern San Joaquin Valley and in the San Francisco Bay area. Further details of this simulation, including model domain, resolution, and base case emissions are described in Steiner et al. (2006) and are described only briefly here. The model domain (96 grid cells in the eastwest direction and 117 grid cells in the north-south direction) is focused on central California (approximately $34.5^{\circ} \mathrm{N}$ to $39^{\circ} \mathrm{N}$ and $118.5^{\circ} \mathrm{W}$ to $123^{\circ} \mathrm{W}$ ), with a horizontal resolution of $4 \mathrm{~km}$. There are 27 terrain-following vertical sigma layers from the surface to approximately $100 \mathrm{mb}$, where the first near-surface layer is approximately $20 \mathrm{~m}$. Concentrations presented here are averaged over the first eleven vertical layers of the atmosphere, representing approximately $500 \mathrm{~m}$ above ground level. This vertical averaging was utilized to approximate an average boundary layer concentration and account for vertical and horizontal mixing.

Mesoscale meteorological simulations (MM5) are used to drive the CMAQ simulations, and were performed as part of the Central California Ozone Study (CCOS). MM5 testing over the region indicated that the model performs optimally when including the NOAH LSM, Eta boundary layer scheme, and FDDA nudging techniques (Wilczak et al., 2004). The use of the nudged simulation yields good agreement between observed and modeled wind speeds (within $0.2 \mathrm{~m} / \mathrm{s}$ averaged over the full domain, and a maximum difference of $1-2 \mathrm{~m} / \mathrm{s}$ ) and wind direction (Wilczak et al., 2004; results available online at http://www.etl.noaa.gov/programs/ modeling/cos/data/). Observed and modeled boundary layer heights in the San Joaquin Valley agree within about $20 \%$, and the model captures the spatial distribution of variable boundary layer height well compared to observations. Greater discrepancies between the observed and modeled boundary layer height are noted in the coastal regions; however, the analysis here focuses on the Central Valley and Sierra Mountains.

Anthropogenic emission estimates are based on point, area and mobile sources from gridded emission inventory data supplied by the California Air Resources Board (CARB) for a summer 1990 air pollution episode (Marr et al., 2002), 
and scaled to include changes due to growth and technology to the year 2000 (Marr, 2002). The mobile portion of this inventory was further adjusted to reflect on-road and ambient measurements of pollutant emissions, the ratios of these emissions, and different activity patterns by time of day and day of week for gasoline versus diesel engines. This resulted in an increase in VOC emissions and a decrease in $\mathrm{NO}_{\mathrm{x}}$ emissions relative to the original CARB inventory (Marr et al., 2002; Harley et al., 2005). Biogenic VOC emissions for these simulations include isoprene, monoterpenes, and methylbutenol, with emissions estimated hourly over the model domain using the BEIGIS modeling system (Scott and Benjamin, 2003).

The second simulation emulates future climate by using temperature changes estimated from a $2 \times \mathrm{CO}_{2}$ regional climate simulation (Snyder et al., 2002). An increase in temperature is predicted from the doubling of $\mathrm{CO}_{2}$, and this increase is applied to the present-day model atmospheric temperatures. We allow temperature to affect the simulation in three ways: 1) by altering the kinetics of the gas phase chemistry, 2) by increasing the atmospheric water vapor content due to the increased temperature, and 3) by increasing the emissions of biogenic VOC compounds, which generally increase with temperature. This simulation does not include a change in vegetation or land cover due to the temperature increase, which could alter biogenic VOC emissions through changes in vegetation species composition and biomass. The changes to temperature, water vapor, and biogenic VOC emissions are referred to as the "combined climate simulation" and are detailed in Steiner et al. (2006), therefore we provide only a brief summary of this simulation here. Temperature increases about $1.5^{\circ} \mathrm{C}$ along the coast to approximately $4^{\circ} \mathrm{C}$ in the Sierra Nevada Mountains, with a similar spatial impact on atmospheric moisture. The higher temperatures increase biogenic VOC emissions by $20-45 \%$. Together, these three temperature impacts are included in a single simulation and we utilize this combined climate simulation to estimate the impact of future climate on VOC reactivity.

\subsection{VOC classification}

Gas phase chemistry is modeled in CMAQ using the SAPRC99 mechanism, which lumps VOC into functional groups based on structure and reactivity (Carter, 2000). For this analysis, we group VOC into four categories reflecting different primary emission sources and secondary chemistry in the atmosphere: anthropogenic, biogenic, aldehydes and other oxygenated VOC. Anthropogenic and biogenic VOC reactivity are solely from primary sources and reflect the majority of primary VOC emissions provided to the chemistry model. Aldehydes and other oxygenated VOC reactivity include a minor primary emission source plus a secondary source from oxidation of all VOC in the atmosphere.

Anthropogenic VOC includes ethene (ETHE), five lumped categories of alkanes (ALK1-ALK5), and two lumped cate-

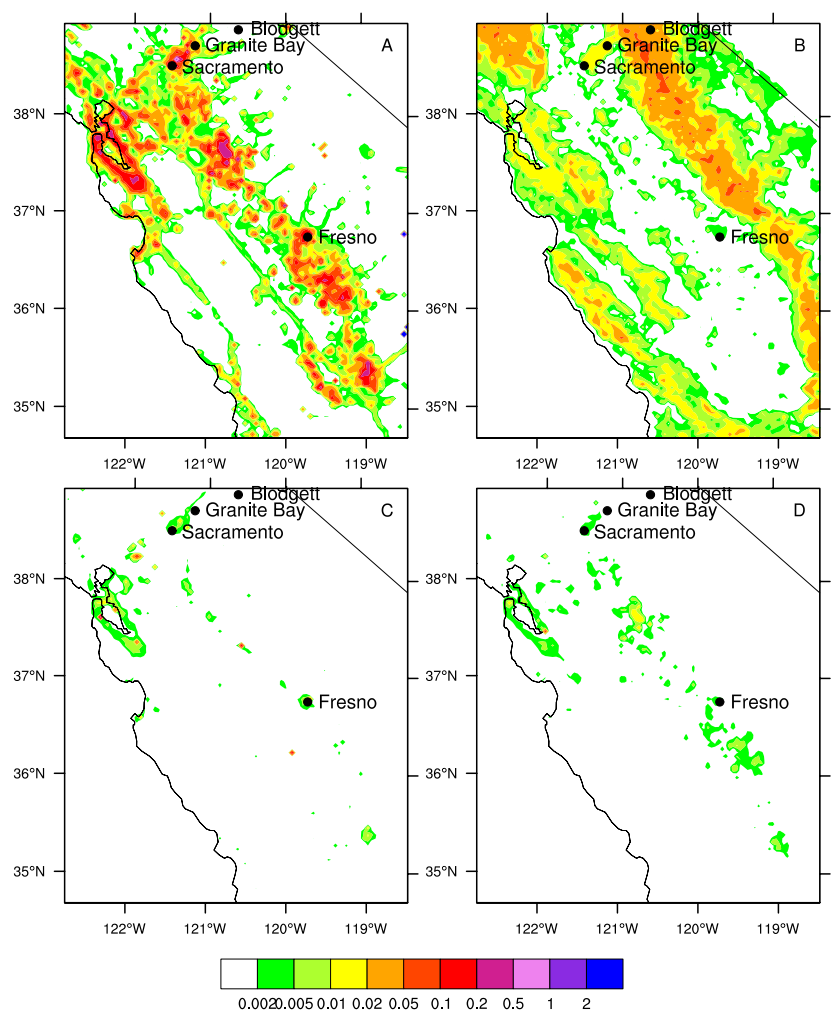

Fig. 1. Primary, present-day emissions $\left(\mathrm{mol} \mathrm{s}^{-1}\right)$ for four VOC categories: (a) anthropogenic, (b) biogenic, and (c) aldehyde and (d) other oxygenated VOC. All figures display the average emission flux at 09:00 LT.

gories each for olefins (OLE1, OLE2) and aromatics (ARO1, ARO2). Model anthropogenic species are listed in Table 1 along with average morning contributions to total VOC reactivity. The modeled anthropogenic VOC category represents the total amount of anthropogenic hydrocarbon primary emissions (spatial distribution shown in Fig. 1a) based on gridded emission inventory data supplied by the California Air Resources Board and modified by Marr et al. (2002) and Harley et al. (2005). Emissions of anthropogenic VOC are dominated by higher alkanes (ALK3-ALK5) and ethene.

The second category, biogenic VOC, includes primary emissions of isoprene, monoterpenes, and methylbutenol from natural, agricultural, and urban areas estimated with the BEIGIS model (Scott and Benjamin, 2003) (Fig. 1b). Anthropogenic and biogenic VOC are emitted in similar magnitude although their spatial distributions differ, with anthropogenic VOC emitted from dense urban areas and transportation corridors and biogenic species emitted from California's natural and crop vegetation. We note that urban locations in the northern portion of the modeling domain (e.g. the San Francisco Bay area and the Sacramento metropolitan area) still have significant amounts of biogenic VOC emissions from isoprene, while agricultural areas in the Central Valley are low in both anthropogenic and biogenic VOC emissions. 
Table 1. Average morning modeled $\mathrm{R}_{\mathrm{OH}}$, VOC for four VOC categories: anthropogenic, biogenic, aldehydes, and other oxygenated VOC. $k_{\mathrm{OH}}$ values for anthropogenic VOC reactions (alkanes, olefins and aromatics) are in $\mathrm{ppm}^{-1} \mathrm{~min}^{-1}$ (Carter, 2000).

\begin{tabular}{|c|c|c|c|c|c|}
\hline CMAQ Category & Description & Sacramento & Fresno & Granite Bay & Blodgett Forest \\
\hline Anthropogenic & & 2.635 & 1.988 & 1.590 & 0.146 \\
\hline ETHENE & Ethene & 0.516 & 0.330 & 0.326 & 0.036 \\
\hline ALK1 & alkanes/non-aromatics, $200<k_{\mathrm{OH}}<500$ & 0.015 & 0.046 & 0.017 & 0.004 \\
\hline ALK2 & alkanes/non-aromatics, $500<k_{\mathrm{OH}}<2500$ & 0.028 & 0.028 & 0.019 & 0.004 \\
\hline ALK3 & alkanes/non-aromatics, $2500<k_{\mathrm{OH}}<5000$ & 0.088 & 0.133 & 0.066 & 0.005 \\
\hline ALK4 & alkanes/non-aromatics,5000 $<k_{\mathrm{OH}}<10000$ & 0.231 & 0.238 & 0.177 & 0.010 \\
\hline ALK5 & alkanes/non-aromatics, $k_{\mathrm{OH}}>10000$ & 0.285 & 0.282 & 0.196 & 0.007 \\
\hline OLE1 & Alkenes with $k_{\mathrm{OH}}<70000$, usu. terminal alkenes & 0.506 & 0.230 & 0.305 & 0.036 \\
\hline OLE2 & Alkenes with $k_{\mathrm{OH}}>70000$, usu. internal or disubstituted alkenes & 0.364 & 0.215 & 0.017 & 0.016 \\
\hline ARO1 & Aromatics with $k_{\mathrm{OH}}<20000$, usu. toluene and monoalkyl benzenes & 0.131 & 0.104 & 0.101 & 0.011 \\
\hline $\mathrm{ARO} 2$ & Aromatics with $k_{\mathrm{OH}}>20000$, usu. xylenes and polyalkyl benzenes & 0.546 & 0.429 & 0.384 & 0.019 \\
\hline Biogenic & & 1.893 & 0.392 & 0.318 & 6.124 \\
\hline ISOP & Isoprene & 1.473 & 0.349 & 0.240 & 2.570 \\
\hline TRP & Biogenic alkenes less isoprene & 0.356 & 0.046 & 0.022 & 0.359 \\
\hline $\mathrm{MBO}$ & 2-methyl-3-buten-2-ol & 0.236 & 0.049 & 0.037 & 2.885 \\
\hline Aldehydes & & 1.642 & 1.492 & 1.506 & 1.071 \\
\hline $\mathrm{HCHO}$ & Formaldehyde & 0.908 & 0.629 & 0.862 & 0.411 \\
\hline $\mathrm{CCHO}$ & Acetaldehyde and glycolaldehyde & 0.354 & 0.444 & 0.323 & 0.309 \\
\hline $\mathrm{RCHO}$ & Lumped C3+ aldehydes & 0.321 & 0.353 & 0.270 & 0.321 \\
\hline BALD & Aromatic aldehydes & 0.012 & 0.010 & 0.011 & 0.001 \\
\hline GLY & Glyoxal & 0.014 & 0.015 & 0.012 & 0.003 \\
\hline MGLY & Methyl glyoxal \& higher a-dicarbonyls & 0.033 & 0.041 & 0.028 & 0.026 \\
\hline \multicolumn{2}{|l|}{ Other Oxygenated } & 0.399 & 0.338 & 0.174 & 0.413 \\
\hline ACET & Acetone & 0.003 & 0.008 & 0.002 & 0.004 \\
\hline MEK & Ketones with $k_{\mathrm{OH}}<5 \times 10^{-12} \mathrm{~cm}^{3} \mathrm{molec}^{-1} \mathrm{~s}^{-1}$ & 0.010 & 0.029 & 0.009 & 0.008 \\
\hline $\mathrm{MEOH}$ & Methanol & 0.002 & 0.003 & 0.001 & 0.001 \\
\hline PHEN & Phenol & 0.0003 & 0.0002 & 0.0001 & 0.00002 \\
\hline CRES & Cresols & 0.010 & 0.010 & 0.009 & 0.001 \\
\hline MVK & Unsaturated ketones & 0.049 & 0.043 & 0.029 & 0.070 \\
\hline MACR & Methacrolein & 0.154 & 0.050 & 0.026 & 0.105 \\
\hline IPRD & Unsaturated aldehydes other than acrolein and methacrolein & 0.105 & 0.076 & 0.043 & 0.153 \\
\hline PROD2 & Ketones with $k_{\mathrm{OH}}<5 \times 10^{-12} \mathrm{~cm}^{3} \mathrm{molec}^{-1} \mathrm{~s}^{-1}$ & 0.066 & 0.119 & 0.055 & 0.071 \\
\hline
\end{tabular}

The third category, aldehydes, includes primary emissions sources as well as the secondary oxidation products of anthropogenic and biogenic VOC. In the model, we consider six aldehyde categories, detailed in Table 1. Primary anthropogenic emissions of aldehydes in the model are shown in Fig. 1c and include formaldehyde (HCHO), acetaldehyde (CCHO), benzaldehyde, other $\mathrm{C} 3+$ aldehydes ( $\mathrm{RCHO}$ ), glyoxal (GLY) and methylglyoxal (MGLY). Primary urban emissions of aldehydes are dominated by $\mathrm{HCHO}$ and $\mathrm{CCHO}$.

The fourth category, other oxygenated VOC, includes nine model categories (Table 1). Primary emissions (Fig. 1d) include acetone, C4+ ketones (MEK), phenol, cresol and methanol, and the dominant emissions of oxygenated species in urban regions are MEK, methanol and acetone, although aldehyde and other oxygenated VOC emissions tend to be 1-2 orders of magnitude less than anthropogenic or biogenic VOC emissions. The primary emissions of aldehy- des and other oxygenated VOC in the model are solely anthropogenic and are located near urban and industrial areas. These anthropogenically-emitted species can also be produced in the atmosphere as secondary products from the oxidation of anthropogenic and biogenic VOC. Additional other oxygenated VOC that are a result of atmospheric oxidation only include PROD2 (a lumped oxygenated VOC that represents secondary products from both biogenic and anthropogenic VOC oxidation), MVK, MACR, and IPRD (resulting primarily from biogenic VOC oxidation).

We note a few caveats to the emissions and description of the other oxygenated VOC category that suggest this VOC category may be underestimated. Several compounds grouped in the anthropogenic VOC category include primary emissions of oxygenated species such as ethanol, other alcohols, glycols, and some ethers. One example is methyl tert-butyl ether, which is included as an anthropogenic VOC 
Table 2. Measured chemical species in each of the four VOC categories, ranked in order of reaction rate. List of species used to estimate calculated $\mathrm{R}_{\mathrm{OH}, \mathrm{VOC}}$ at each of the following sampling locations: Sacramento PAMS (2000 data), Blodgett Forest Research Station (22/07/2001-19/09/2001), and Granite Bay (16/07/2001-17/09/2001), with average afternoon concentrations (ppb). CMAQ lumped categories for each measured species are indicated for comparison with modeled $\mathrm{R}_{\mathrm{OH}, \mathrm{VOC}}$.

\begin{tabular}{|c|c|c|c|c|c|}
\hline $\begin{array}{l}\text { VOC Categories and } \\
\text { Chemical Species }\end{array}$ & $k_{\mathrm{OH}}^{\mathrm{a}} \times 10^{-12}\left(\mathrm{~cm}^{3} \operatorname{molec}^{-1} \mathrm{~s}^{-1}\right)$ & $\mathrm{PAMS}^{\mathrm{b}}$ & Blodgett ${ }^{b}$ & Granite Bay ${ }^{b}$ & CMAQ \\
\hline \multicolumn{6}{|l|}{ Anthropogenic VOC } \\
\hline 1,3-butadiene & 68.3 & & & 0.026 & OLE2 \\
\hline trans-2-pentene & 67.0 & 0.107 & & 0.016 & OLE2 \\
\hline trans-2-butene & 66.0 & 0.130 & & 0.009 & OLE2 \\
\hline cis-2-pentene & 65.0 & 0.099 & & 0.007 & OLE2 \\
\hline 2-methyl-1-butene & 60.7 & & & 0.019 & OLE2 \\
\hline styrene & 58.0 & 0.089 & & & OLE2 \\
\hline cis-2-butene & 57.9 & 0.121 & & & OLE2 \\
\hline 1,3,5-trimethylbenzene & 57.5 & 0.836 & & & $\mathrm{ARO} 2$ \\
\hline cyclopentene & 57.0 & & & 0.004 & OLE2 \\
\hline 2-methylpropene (isobutene) & 52.8 & & 0.027 & 0.081 & OLE2 \\
\hline 1,2,4-trimethylbenzene & 37.5 & 0.084 & & & $\mathrm{ARO} 2$ \\
\hline 1,2,3-trimethylbenzene & 32.7 & 0.174 & & & ARO2 \\
\hline 1-butene & 32.2 & 0.144 & 0.038 & 0.034 & OLE1 \\
\hline 1-pentene & 31.4 & 0.118 & & 0.036 & OLE1 \\
\hline propene & 30.0 & 1.029 & & 0.367 & OLE1 \\
\hline m-xylene & 23.6 & $1.792^{\mathrm{c}}$ & & 0.240 & ARO2 \\
\hline m-ethyltoluene & 17.1 & 0.018 & & & ARO2 \\
\hline p-xylene & 14.3 & $1.792^{\mathrm{c}}$ & & 0.133 & $\mathrm{ARO} 2$ \\
\hline m-diethylbenzene & 14.2 & & & & $\mathrm{ARO} 2$ \\
\hline o-xylene & 13.7 & 0.296 & & 0.123 & $\mathrm{ARO} 2$ \\
\hline o-ethyltoluene & 12.3 & 0.184 & & & ARO2 \\
\hline n-undecane & 12.9 & 2.021 & & & ALK5 \\
\hline p-ethyltoluene & 11.4 & 0.073 & & & $\mathrm{ARO} 2$ \\
\hline n-decane & 11.2 & 0.070 & & & ALK5 \\
\hline methylcyclohexane & 10.0 & 0.170 & & & ALK5 \\
\hline n-nonane & 9.91 & 0.063 & & & ALK5 \\
\hline n-octane & 8.60 & 0.086 & & & ALK5 \\
\hline 3-methylheptane & 8.56 & 0.073 & & & ALK5 \\
\hline 2-methylheptane & 8.28 & 0.903 & & & ALK5 \\
\hline p-diethylbenzene & 8.11 & 0.097 & & & $\mathrm{ARO} 2$ \\
\hline 3-methylhexane & 7.16 & 0.232 & & & ALK5 \\
\hline ethylbenzene & 7.10 & 0.497 & 0.021 & 0.080 & ARO1 \\
\hline cyclohexane & 7.10 & 0.193 & & & ALK5 \\
\hline 2,3,4-trimethylpentane & 7.10 & 0.010 & & & ALK5 \\
\hline n-heptane & 6.98 & 0.208 & & 0.243 & ALK5 \\
\hline methylcyclopentane & $6.80^{\mathrm{d}}$ & 0.353 & & & ALK4 \\
\hline isopropylbenzene & 6.50 & 0.085 & & & ARO1 \\
\hline toluene & 6.40 & 0.340 & 0.085 & 0.488 & ARO1 \\
\hline 2,3-dimethylpentane & 6.10 & 0.119 & & & ALK5 \\
\hline propyne (methyl acetylene) & 5.90 & & 0.022 & 0.022 & ALK4 \\
\hline 2,3-dimethylbutane & 5.75 & 0.147 & & & ALK4 \\
\hline n-propylbenzene & 5.70 & 0.187 & & & ARO1 \\
\hline
\end{tabular}

in the ALK3 category (Table 2) despite the oxygenated nature of the compound. However, MTBE and other similar compounds tend to have low reactivity and comprise a small portion of the total anthropogenic VOC emissions. Addi- tionally, we have not included primary biogenic emissions of oxygenated VOC. Crops and natural vegetation may directly emit some aldehydes and other oxygenated VOC including acetone, methanol, acetaldehyde and a wide variety of other 
Table 2. Continued.

\begin{tabular}{|c|c|c|c|c|c|}
\hline \multicolumn{6}{|c|}{ Anthropogenic VOC, cont. } \\
\hline 3-methylpentane & 5.40 & 0.294 & 0.011 & $0.351^{\mathrm{e}}$ & ALK4 \\
\hline n-hexane & 5.40 & 0.276 & 0.015 & 0.135 & ALK4 \\
\hline 3-methyl-1-butene & 5.32 & & & 0.016 & OLE1 \\
\hline 2-methylpentane & 5.30 & 0.626 & 0.022 & $0.351^{\mathrm{e}}$ & ALK4 \\
\hline 2-methylhexane & 5.10 & 0.154 & & & ALK5 \\
\hline 2,4-dimethylpentane & 5.00 & 0.091 & & & ALK4 \\
\hline cyclopentane & 4.92 & 0.122 & & 0.041 & ALK4 \\
\hline n-pentane & 3.91 & 0.567 & 0.038 & 0.259 & ALK4 \\
\hline isopentane & 3.70 & 1.579 & 0.067 & 0.665 & ALK4 \\
\hline methyl tert-butyl ether & 2.96 & & & 1.943 & ALK3 \\
\hline 2,2-dimethylbutane & 2.34 & 0.112 & & & ALK4 \\
\hline n-butane & 2.34 & 0.779 & 0.080 & 0.443 & ALK3 \\
\hline isobutane & 2.15 & 0.498 & 0.045 & 0.300 & ALK3 \\
\hline benzene & 1.17 & 0.136 & 0.227 & 0.152 & BENZ \\
\hline propane & 1.07 & 2.406 & & 1.489 & ALK2 \\
\hline acetylene & 0.78 & 1.587 & & & ALK2 \\
\hline ethene & 0.236 & 1.648 & & & ETHE \\
\hline ethane & 0.236 & 2.017 & & & ALK1 \\
\hline 2,2-dimethylpropane & 0.0000179 & & & 0.005 & ALK2 \\
\hline \multicolumn{6}{|l|}{ Biogenic VOC } \\
\hline d-limonene & 171.0 & & & 0.031 & TRP1 \\
\hline isoprene & 103.0 & 1.521 & 0.262 & 0.516 & ISOP \\
\hline 3-carene & 88.0 & & & 0.010 & TRP1 \\
\hline b-pinene & 80.5 & & 0.125 & & TRP1 \\
\hline methylbutenol & 64.0 & & 1.135 & & MBO \\
\hline a-pinene & 55.1 & & 0.123 & 0.035 & TRP1 \\
\hline \multicolumn{6}{|l|}{ Aldehydes } \\
\hline hexanal & $31.7^{\mathrm{f}}$ & & & 0.276 & $\mathrm{RCHO}$ \\
\hline pentanal & $29.9^{f}$ & & 0.064 & 0.118 & $\mathrm{RCHO}$ \\
\hline acetaldehyde & 15.8 & 1.398 & 1.386 & 1.417 & $\mathrm{CCHO}$ \\
\hline formaldehyde & $9.20^{\mathrm{g}}$ & 2.658 & & & $\mathrm{HCHO}$ \\
\hline \multicolumn{6}{|l|}{ Oxygenated VOC } \\
\hline 3-methylfuran & $93.5^{\mathrm{h}}$ & & & 0.009 & \\
\hline methacrolein & 35.0 & & 0.289 & 0.213 & MACR \\
\hline methyl vinyl ketone & 18.8 & & 0.331 & 0.309 & MVK \\
\hline ethanol & 3.27 & & & 2.257 & ALK3 \\
\hline methyl ethyl ketone & 1.15 & & & 0.213 & MEK \\
\hline methanol & 0.94 & & 10.735 & 7.467 & MEOH \\
\hline acetone & 0.22 & & 2.507 & 2.911 & ACET \\
\hline
\end{tabular}

${ }^{\mathrm{a}} k_{\mathrm{OH}}$ values based on Atkinson (1994) unless noted otherwise.

b Average AM (06:00-08:00 a.m. local time) concentrations over the sampling period, in ppb. PAMS data listed is an average of the four sites in the Sacramento metropolitan area.

${ }^{c}$ PAMS stations report co-eluting $\mathrm{m}$ - and p-xylene as a single sum, therefore concentrations shown here are the sum of these two isomers.

d Estimated from Kwok and Atkinson (1995).

e Granite Bay measurements include total methylpentanes, here listed as 2-methylpentane.

${ }^{\mathrm{f}}$ Papagni et al. (2000)

g Carter (2000)

h Atkinson et al. (1989) 
alcohols, ketones, esters, and ethers (Kesselmeier and Staudt, 1999; Schade and Goldstein, 2001). However, measurements and modeling efforts have yet to thoroughly quantify these species on the scale needed for regional emissions modeling, and they are not included in our biogenic VOC emissions inventory.

\subsection{Ground-based measurements}

We utilize ground-based measurements at four locations in central California (marked in Fig. 1). For two locations, Sacramento and Fresno, we use observations from the Photochemical Assessment Monitoring Stations (PAMS) network. At eleven sites in four different geographic regions in California (in Sacramento, Fresno, Kern and Madera counties), ground-based $\mathrm{O}_{3}, \mathrm{CO}, \mathrm{NO}_{\mathrm{x}}$, and VOC measurements have been collected from 1994 to the present. The VOC dataset consists of a long-term record of 55 VOC species (see Table 2) collected at 3-h intervals, including alkanes, alkenes and aromatics (data available at www.epa.gov/air/ oaqps/pams). This dataset predominantly reflects the anthropogenic VOC category as defined in Sect. 2.2, with isoprene measurements at these locations representing only a portion of the biogenic VOC category. Selected PAMS sites measure a suite of carbonyl species, including formaldehyde and acetaldehyde, and we include these measurements when available. Here, we include concurrent $\mathrm{VOC}$ and $\mathrm{NO}_{\mathrm{x}}$ data from the summer of 2000 for the Sacramento (four measurement sites) and Fresno (three measurement sites) metropolitan areas. While the PAMS data have been known to have several artifacts in the hydrocarbon and aldehyde samples due to the nature of canister samples (McClenney et al., 2002), we utilize this data here in the absence of in-situ VOC sampling in the region and note that these results should be reviewed with caution with respect to the carbonyl species.

A third sampling location, Granite Bay, was established in the summer of 2001 to evaluate the transport of pollutants at the eastern edge and downwind of Sacramento. $\mathrm{NO}_{2}$ was measured from 19/07/2001-15/09/2001, and $\mathrm{NO}_{\mathrm{x}}$ concentrations are estimated from $\mathrm{NO}_{2}$ photolysis, measured ozone, and modeled $\mathrm{RO}_{2}$ (Cleary et al., 2005). A suite of VOC was measured at the same location, including 28 anthropogenic, 4 biogenic, 4 aldehydes and 7 other oxygenated VOC (Millet et al., 2005). As shown in Table 2, measurements in the anthropogenic, biogenic and other oxygenated VOC categories represent a significant portion of the modeled VOC reactivity, while the aldehyde category is missing the important contribution of $\mathrm{HCHO}$.

The fourth location, Blodgett Forest Research Station, is located in the Sierra Nevada mountains approximately $75 \mathrm{~km}$ ENE of Sacramento, and represents a rural site where concentrations and fluxes of biogenic VOC compounds have been measured during summer months since 1997 (e.g., Lamanna and Goldstein, 1999). Additional VOC concentrations were measured in 2001 in conjunction with Granite
Bay measurements. These include a limited number of anthropogenic (10 species), aldehydes (2 species), other oxygenated VOC (4 species), and the dominant biogenic VOC (4 species) (Table 2). While the number of VOC species measured at Blodgett is small compared to other sites, the measurements comprise the major biogenic species emitted and are likely representative of VOC chemistry at the site. Additionally, $\mathrm{NO}_{\mathrm{x}}$ has been measured at the site (Day et al., 2003, 2007), and data were filtered for concurrent $\mathrm{NO}_{\mathrm{x}}$ and VOC measurements.

\section{$2.4 \mathrm{R}_{\mathrm{OH} \text {,total }}$ and $\mathrm{R}_{\mathrm{OH}, \mathrm{VOC}}$ definitions}

Here, we define the total $\mathrm{OH}$ reactivity $\left(\mathrm{R}_{\mathrm{OH}, \text { total }}, \mathrm{s}^{-1}\right)$ as $\mathrm{OH}$ loss with the following species: $\mathrm{CO}, \mathrm{CH}_{4}, \mathrm{NO}_{2}$, anthropogenic VOC, biogenic VOC, aldehydes, and other oxygenated VOC:

$$
\begin{aligned}
& \mathrm{R}_{\mathrm{OH}, \text { total }}=k_{\mathrm{CO}+\mathrm{OH}}[\mathrm{CO}]+k_{\mathrm{CH}_{4}+\mathrm{OH}}\left[\mathrm{CH}_{4}\right]+k_{\mathrm{NO}_{2}+\mathrm{OH}}\left[\mathrm{NO}_{2}\right] \\
& +\sum_{n=1, \text { navoc }} k_{n+\mathrm{OH}}[\mathrm{aVOC} \text {, meas }]+\sum_{n=1, \text { nbvoc }} k_{n+\mathrm{OH}}\left[\mathrm{bVOC}_{n, \text { meas }}\right] \\
& +\sum_{n=1, \text { naldvoc }} k_{n+\mathrm{OH}}\left[\mathrm{aldVOC}_{n, \text { meas }}\right]+\sum_{n=1, \text { noxvoc }} k_{n+\mathrm{OH}}\left[\mathrm{oxVOC}_{n, \text { meas }}\right]
\end{aligned}
$$

where navoc (nbvoc, naldvoc, noxvoc) is the number of anthropogenic (biogenic, aldehyde, other oxygenated) VOC species, $k_{n+\mathrm{OH}}$ is the rate coefficient $\left(\mathrm{cm}^{3}\right.$ molecules $\left.{ }^{-1} \mathrm{~s}^{-1}\right)$ and $\left[\mathrm{VOC}_{n \text {,meas }}\right]$ is the measured VOC concentration. VOC reactivity $\left(\mathrm{R}_{\mathrm{OH}}, \mathrm{VOC}\right)$ is calculated from the four VOC categories only:

$$
\begin{aligned}
& \mathrm{R}_{\mathrm{OH}, \mathrm{VOC}}=\sum_{n=1, \text { navoc }} k_{n+\mathrm{OH}}\left[\mathrm{aVOC}_{n, \text { meas }}\right]+\sum_{n=1, \mathrm{nbvoc}} k_{n+\mathrm{OH}}\left[\mathrm{bVOC}_{n, \text { meas }}\right] \\
& +\sum_{n=1, \text { naldvoc }} k_{n+\mathrm{OH}}\left[\mathrm{aldVOC}_{n, \text { meas }}\right]+\sum_{n=1, \text { noxvoc }} k_{n+\mathrm{OH}}\left[\mathrm{oxVOC}_{n, \text { meas }}\right]
\end{aligned}
$$

Reactivities are calculated from ground-based $\mathrm{CO}, \mathrm{CH}_{4}$, $\mathrm{NO}_{2}$ and VOC concentrations and kinetic rate coefficients calculated from measured temperature and pressure (Table 2).

Modeled reactivities are determined from integrated reaction rates calculated by CMAQ, which estimates the loss rate of each species that reacts with $\mathrm{OH}$ integrated over each hour:

$\mathrm{OH}_{\mathrm{loss}}(t+\Delta t)=\mathrm{OH}_{\mathrm{loss}}(t)+\int_{t}^{t+\Delta t} k_{n+\mathrm{OH}}[\mathrm{OH}][n] d t$

$\mathrm{VOC}_{\text {loss }}(t+\Delta t)=\mathrm{VOC}_{\text {loss }}(t)+\int_{t}^{t+\Delta t} k_{n+\mathrm{OH}}[\mathrm{OH}][\mathrm{VOC}] d t$

where $\mathrm{OH}_{\text {loss }}$ and $\mathrm{VOC}_{\text {loss }}$ is the integrated reaction rate of each species $\left(\mathrm{ppb} \mathrm{hr}^{-1}\right), \Delta t$ is the integration time of the chemical solver, $k_{n+\mathrm{OH}}$ is the kinetic rate constant of species 

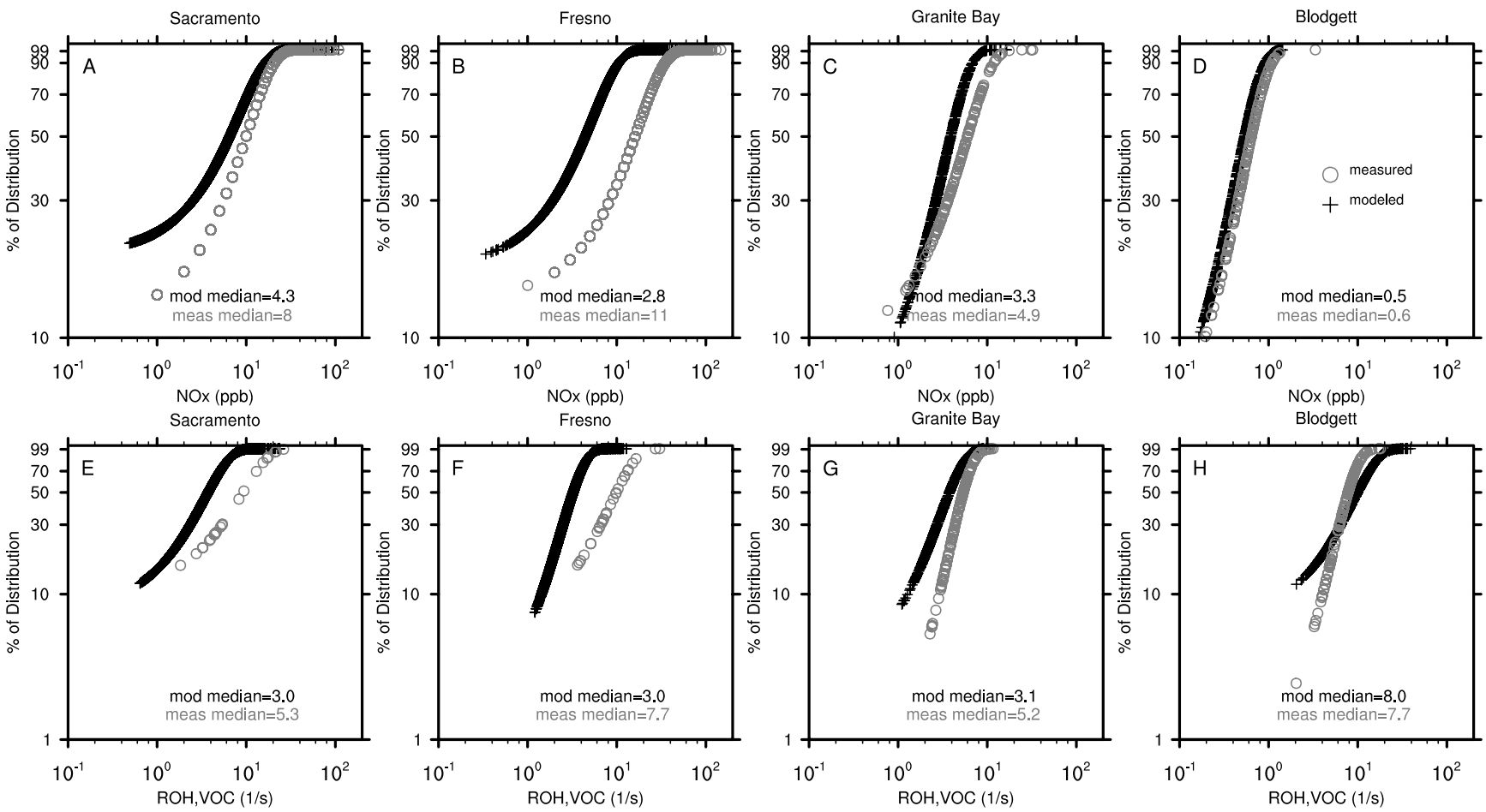

Fig. 2. Measured (gray circles) versus modeled (black crosses) cumulative distribution functions for (a) Sacramento $N_{\mathrm{x}}$, (b) Fresno $\mathrm{NO}_{\mathrm{x}}$, (c) Granite Bay $\mathrm{NO}_{\mathrm{x}}$, (d) Blodgett $\mathrm{NO}_{\mathrm{x}}$, and (e) Sacramento $\mathrm{R}_{\mathrm{OH}, \mathrm{VOC}}$, (f) Fresno $\mathrm{R}_{\mathrm{OH}, \mathrm{VOC}}$, (g) Granite Bay $\mathrm{R}_{\mathrm{OH}} \mathrm{VOC}$, and (h) Blodgett $\mathrm{R} \mathrm{OH}, \mathrm{VOC}$.

$n$ with the $\mathrm{OH}$ radical, and $[\mathrm{OH}]$ and $[n]$ represent concentrations at time $t$ (Byun and Ching, 1999). For OH loss, $n$ includes $\mathrm{CO}, \mathrm{CH}_{4}, \mathrm{NO}_{2}$, and the four VOC categories. For VOC loss, $n$ includes only the four VOC categories. This representation provides an accurate method of assessing the loss rates of each species with $\mathrm{OH}$. In order to compare the model loss rates with observations in California and elsewhere, we assume that the modeled $\mathrm{OH}$ concentrations are relatively stable over the timescale of the hour of integration and calculate the modeled $\mathrm{OH}$ and $\mathrm{VOC}$ reactivity as:

$\mathrm{R}_{\mathrm{OH}, \text { total }}=\frac{\mathrm{OH}_{\text {loss }}}{[\mathrm{OH}]}$

$\mathrm{R}_{\mathrm{OH}, \mathrm{VOC}}=\frac{\mathrm{VOC}_{\text {loss }}}{[\mathrm{OH}]}$

For $\mathrm{R}_{\mathrm{OH}, \mathrm{VOC}}$, we calculate this quantity as the sum of individual species for each of the four VOC categories, considering only daytime modeled and calculated reactivity calculations, when $\mathrm{OH}$ dominates radical reactivity with VOC. We note the definitions of $\mathrm{R}_{\mathrm{OH} \text {,total }}$ and $\mathrm{R}_{\mathrm{OH}, \mathrm{VOC}}$ are closely connected, as changes in concentrations of $\mathrm{CO}, \mathrm{NO}_{2}$ and $\mathrm{CH}_{4}$ will impact $\mathrm{OH}$ concentrations and in turn the rate of VOC reactions. Therefore, $\mathrm{R}_{\mathrm{OH}, \mathrm{VOC}}$ is a subset of $\mathrm{R}_{\mathrm{OH} \text {,total }}$.

\section{Results and discussion}

We use ground-based measurements of $\mathrm{NO}_{2}, \mathrm{CO}$, and VOC

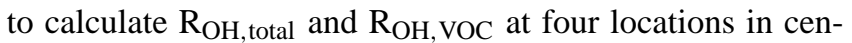
tral California. We compare calculated and modeled reactivities using four metrics: 1) cumulative distribution functions of $\mathrm{NO}_{\mathrm{x}}$ concentrations and $\left.\mathrm{R}_{\mathrm{OH}, \mathrm{VOC}}, 2\right)$ the relationship between $\mathrm{R}_{\mathrm{OH}, \mathrm{VOC}}$ and $\mathrm{NO}_{\mathrm{x}}$ concentration, and 3) speciated contributions to $\mathrm{R}_{\mathrm{OH}}$,total. Additionally, at the Sacramento location we evaluate relationships between speciated $\mathrm{R}_{\mathrm{OH}, \mathrm{VOC}}$ and $\mathrm{NO}_{\mathrm{x}}$. These comparisons evaluate the model performance in order to gain insight into the fast chemistry and the importance of VOC sources in central California.

\subsection{Cumulative distribution functions of $\mathrm{R}_{\mathrm{OH}, \mathrm{VOC}}$ and $\mathrm{NO}_{\mathrm{x}}$}

To determine if the model is reproducing conditions similar to those estimated by ground-based measurements, we evaluate the cumulative distribution functions (CDFs) of $\mathrm{NO}_{\mathrm{x}}$ and $\mathrm{R}_{\mathrm{OH}, \mathrm{VOC}}$. Comparing measured versus modeled CDFs can indicate if the model is able to reproduce the general mode of $\mathrm{NO}_{\mathrm{x}}$ and $\mathrm{R}_{\mathrm{OH}, \mathrm{VOC}}$ in the atmosphere. The CDFs shown in Fig. 2 are based on summertime (01/06/2000-01/09/2000) daytime (6 a.m-6 p.m. local time) data at the four measurement locations described in Sect. 2.4, including two urban locations (Sacramento and Fresno), one suburban location (Granite Bay), and one rural location (Blodgett Forest). Re- 

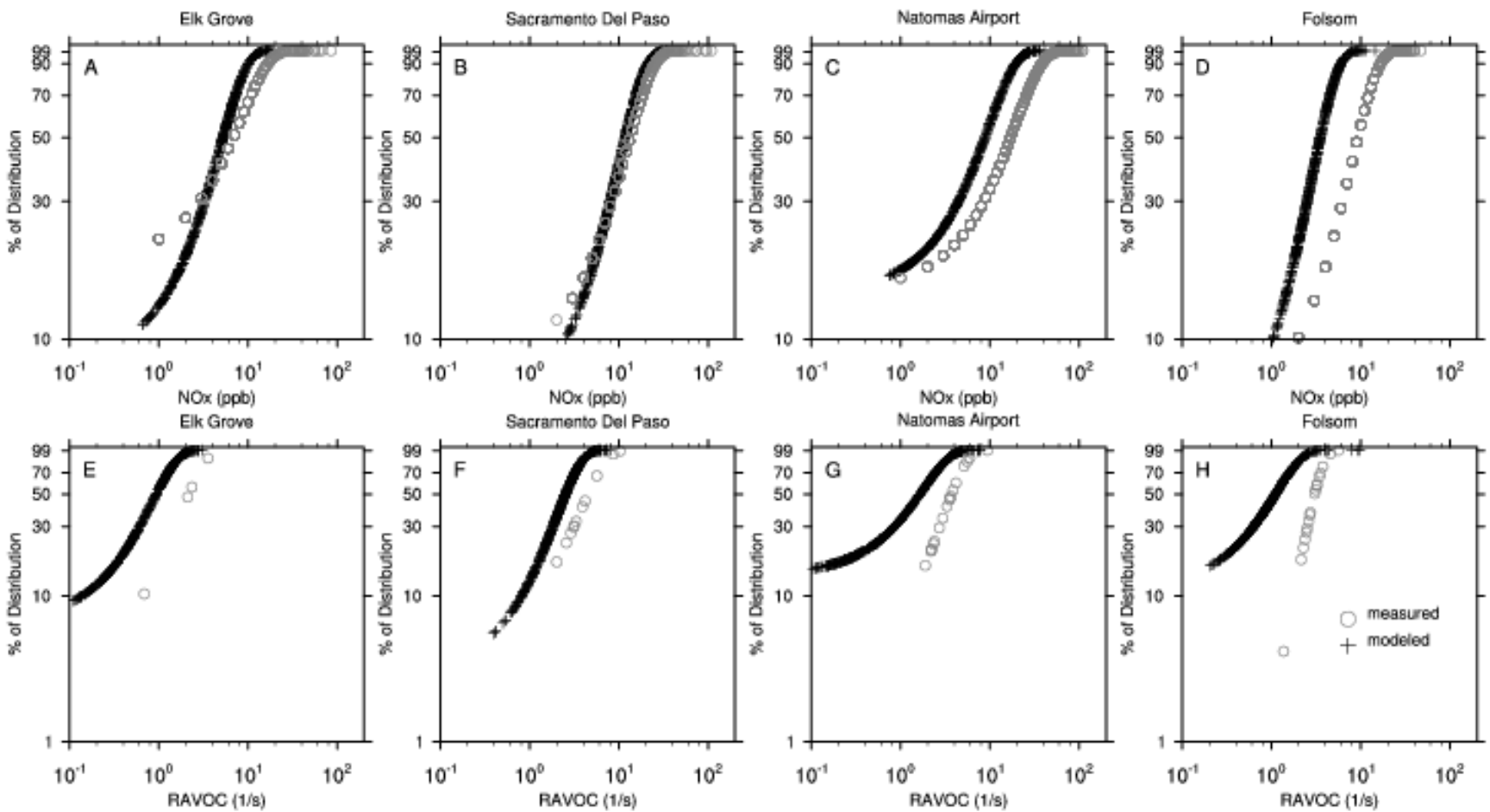

Fig. 3. Measured (gray circles) versus modeled (black crosses) cumulative distribution functions for four Sacramento locations (a) upwind location, Elk Grove $\mathrm{NO}_{\mathrm{x}}$, (b) near-urban location, Sacramento Del Paso Manor $\mathrm{NO}_{\mathrm{x}}$, (c) near-urban location, Natomas Airport $\mathrm{NO}_{\mathrm{x}}$, (d) downwind location, Folsom $\mathrm{NO}_{\mathrm{x}}$, (e) Elk Grove $\mathrm{R}_{\mathrm{AVOC}}$, (f) Sacramento Del Paso Manor $\mathrm{R}_{\mathrm{AVOC}}$, (g) Natomas Airport $\mathrm{R}_{\mathrm{AVOC}}$, and (h) Folsom $\mathrm{R}_{\text {AVOC }}$.

activities calculated from Granite Bay and Blodgett forest are based on measurements conducted during 2001.

In Sacramento during the daytime, the $\mathrm{NO}_{\mathrm{x}} \mathrm{CDF}$ (Fig. 2a) indicates that the model predicts less $\mathrm{NO}_{\mathrm{x}}$ than observed at the lower end of the $\mathrm{NO}_{\mathrm{x}}$ concentrations, while the Fresno results indicate that the model predicts less $\mathrm{NO}_{\mathrm{x}}$ at all times and over the full width of the distribution (Fig. 2b). Mean daytime $\mathrm{NO}_{\mathrm{x}}$ concentrations are less than those measured (Sacramento measured daytime mean $\mathrm{NO}_{\mathrm{x}}=10 \mathrm{ppb}$, modeled mean $\mathrm{NO}_{\mathrm{x}}=7 \mathrm{ppb}$; Fresno measured daytime mean $\mathrm{NO}_{\mathrm{x}}=23.5 \mathrm{ppb}$, modeled mean $\mathrm{NO}_{\mathrm{x}}=5 \mathrm{ppb}$ ). A portion of this daytime discrepancy is likely due to the $\mathrm{NO}_{2}$ chemiluminescence measurement technique employed at the EPA PAMS monitoring locations. This technique is well known to include PAN and other higher oxides of nitrogen in the reported $\mathrm{NO}_{2}$ and thus to have a high bias (e.g., Winer et al., 1974). Recent measurements using current commercial implementations of the technique side by side with instruments that specifically measure $\mathrm{NO}_{2}$ show that high biases of 20$50 \%$ occur routinely (Dunlea et al., 2007; Steinbacher et al., 2007).

Other possibilities for measured and modeled discrepancies include the vertical averaging technique, the impacts of dilution due to meteorological parameters, and the location of urban monitoring stations. Vertical averaging is not a sig- nificant factor, as comparisons of concentrations in the surface layer only (surface to $20 \mathrm{~m}$ ) only impact the top $90 \%$ of the distribution, and indicate that the model still underestimates the majority of the distribution in urban locations (results not shown). Because measured and modeled boundary layer heights are similar in Sacramento (daily maxima approximately 500-600 m) and Fresno (daily maxima approximately $600-800 \mathrm{~m}$ ) during the simulation time period and daytime wind speeds and wind directions agree fairly well (Wilczak et al., 2004; data available at http://www.etl.noaa. gov/programs/modeling/ccos/data/), dilution is not likely a strong factor in the differences in the measured and modeled distribution functions.

Past studies indicate that some PAMS measurement locations are likely too close to mobile sources to be regionally representative (e.g., Murphy et al., 2006a), leading to elevated measurements that should not be reproduced in the relatively large size of the model grid cell $(4 \mathrm{~km} \times 4 \mathrm{~km})$. There are several PAMS sites at the two urban locations, and a portion of the measured versus modeled distribution functions could be influenced by the averaging area of the model grid cells around these different locations. To evaluate the impact of spatial averaging, we examine the $\mathrm{NO}_{\mathrm{x}}$ and anthropogenic $\mathrm{R}_{\mathrm{OH}, \mathrm{VOC}}\left(\mathrm{R}_{\mathrm{AVOC}}\right)$ at four individual locations in Sacramento and compare the observations to the model grid cells in the 

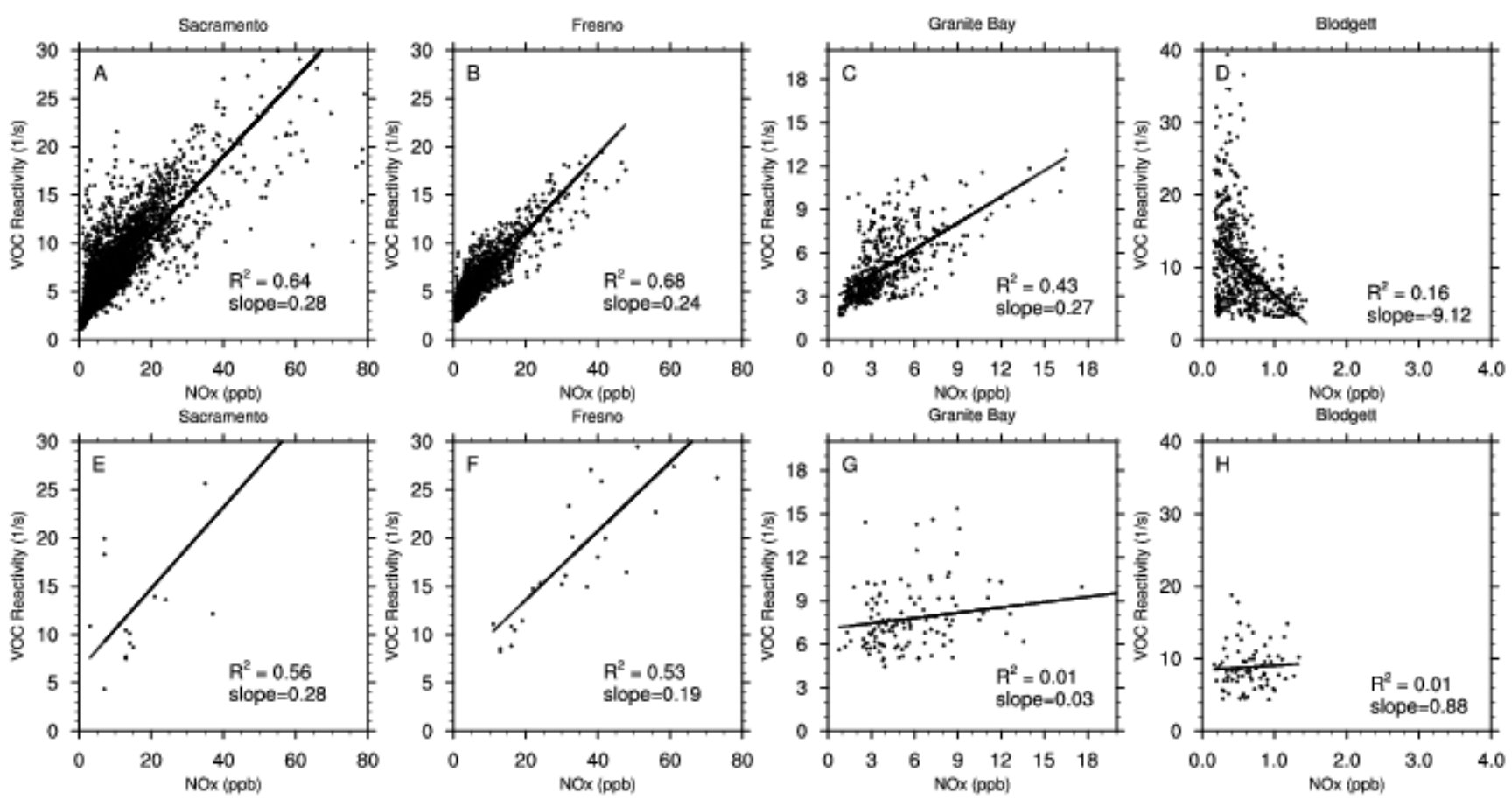

Fig. 4. Total $\mathrm{R}_{\mathrm{OH}}$, VOC $\left(\mathrm{s}^{-1}\right)$ as a function of $\mathrm{NO}_{\mathrm{x}}$ concentrations (ppb), as modeled (a-d) and measured (e-h) in four locations: Sacramento (a, e), Fresno (b, f), Granite Bay (c, g), and Blodgett Forest (d, h). See Table 1 for VOC included in these calculations.

immediate vicinity (Fig. 3). The four PAMS sites represent upwind (Type 1 sites), near urban (Type 2 sites), and downwind locations (Type 3 sites). Elk Grove (Fig. 3a and e) corresponds to an upwind location, while Sacramento Del Paso (Fig. 3b and f) and Natomas Airport (Fig. 3c and g) represent locations near maximum emissions in the urban area, and Folsom (Fig. 3d and h) is located downwind of the urban area and near the location of maximum ozone. The site locations relative to the urban area (e.g., upwind or downwind) do not have a strong impact on the $\mathrm{NO}_{\mathrm{x}}$ and $\mathrm{R}_{\mathrm{AVOC}}$ CDFs. In the upwind location of Elk Grove, the model captures the median $\mathrm{NO}_{\mathrm{x}}$ accurately but does not capture the minimum or the maximum $\mathrm{NO}_{\mathrm{x}}$ concentrations. At the Del Paso urban site (Fig. 3b) the model accurately reproduces the measured CDF while at Natomas Airport (a second urban location) the model consistently predicts less $\mathrm{NO}_{\mathrm{x}}$ than observed. At the downwind site, Folsom, the model predicts less $\mathrm{NO}_{\mathrm{x}}$ and $\mathrm{R}_{\mathrm{AVOC}}$ than observed.

Because these factors do not show a significant impact, this suggests that the discrepancy between measured and modeled $\mathrm{NO}_{\mathrm{x}}$ distributions are due to differences in anthropogenic emissions. Similar to the $\mathrm{NO}_{\mathrm{x}}$ comparisons in Sacramento and Fresno, modeled $\mathrm{R}_{\mathrm{OH}, \mathrm{VOC}}$ is also less than observed throughout the entire distribution (Fig. 2e and f), suggesting an underestimate in modeled anthropogenic VOC emissions as well. Overall, the CDFs indicate that the model under estimates emissions of $\mathrm{NO}_{\mathrm{x}}$ and anthropogenic VOC throughout the Sacramento and Fresno regions.
At Granite Bay, a suburban Sacramento location at the same longitude as Folsom but located approximately $12 \mathrm{~km}$ north, a different $\mathrm{NO}_{2}$ measurement technique is used (Laser Induced Fluorescence (LIF); Thornton et al., 2000; Cleary et al., 2002). Here, the CDFs indicate that observed $\mathrm{NO}_{\mathrm{x}}$ concentrations are fairly well represented by the model in the bottom $50 \%$ of the distribution (similar mode, with modeled median $=3.3 \mathrm{ppb}$ and measured median $=4.9 \mathrm{ppb}$ ), with increasing differences at the high end (model less than observations, Fig. 2c). A similar $\mathrm{NO}_{\mathrm{x}}$ distribution mode is predicted by the model at Granite Bay as at Folsom, but measured $\mathrm{NO}_{\mathrm{x}}$ is lower at Granite Bay than at Folsom. This fact indicates that in the Sacramento region, the overestimate of $\mathrm{NO}_{2}$ by the PAMS monitoring network is one of the dominant sources of the model-measurement difference, but that also some underestimate of emissions by the model is also contributing. For the $\mathrm{R}_{\mathrm{OH}, \mathrm{VOC}}$ distribution (Fig. $2 \mathrm{~g}$ ), the model predicts less $\mathrm{R}_{\mathrm{OH}, \mathrm{VOC}}$ than indicated by measurements, particularly at the lower end of the distribution. This is due in part to the greater contribution of biogenic VOC to calculated $\mathrm{R}_{\mathrm{OH}, \mathrm{VOC}}$ than predicted by the model (see further discussion below in Sect. 3.3).

At Blodgett Forest, a location also with LIF $\mathrm{NO}_{2}$ measurements, measured and modeled $\mathrm{NO}_{\mathrm{x}}$ concentration distributions are similar (Fig. 2d), while the mode and extremes of the $\mathrm{R}_{\mathrm{OH}, \mathrm{VOC}}$ data are significantly different (Fig. 2h). This is likely due to greater values of modeled biogenic $\mathrm{R}_{\mathrm{OH}, \mathrm{VOC}}$, which exhibits a higher reactivity over the narrow range of $\mathrm{NO}_{\mathrm{x}}$ concentrations. Further discussion on the contributions 
of individual VOC categories to $\mathrm{R}_{\mathrm{OH}}$,total and $\mathrm{R}_{\mathrm{OH}, \mathrm{VOC}}$ is included in Sects. 3.3 and 3.4 below.

\subsection{The relationship between $\mathrm{R}_{\mathrm{OH}, \mathrm{VOC}}$ and $\mathrm{NO}_{\mathrm{x}}$}

Another approach to evaluating modeled VOC is to compare the functional relationships of $\mathrm{R}_{\mathrm{OH}}$, VOC versus $\mathrm{NO}_{\mathrm{x}}$ with observations (Fig. 4). In Sacramento (Fig. 4a and e), the measurements and model both span a similar range of $\mathrm{NO}_{\mathrm{x}}$ concentrations (up to $80 \mathrm{ppb}$ ) and $\mathrm{R}_{\mathrm{OH}}$, VOC (up to $30 s^{-1}$ ). The increase in $\mathrm{R}_{\mathrm{OH}, \mathrm{VOC}}$ with $\mathrm{NO}_{\mathrm{x}}$ predicted by the model is close to the observations (slope of 0.28 for both the model and measurements with similar $R^{2}$ values), however the sparse data in Sacramento limits the robustness of this result. In Fresno (Fig. $4 \mathrm{~b}$ and $\mathrm{f}$ ), $\mathrm{NO}_{\mathrm{x}}$ concentrations and $\mathrm{R}_{\mathrm{OH}, \mathrm{VOC}}$ range up to $60 \mathrm{ppb}$ and $30 \mathrm{~s}^{-1}$, respectively, for both measured and modeled data, with similar slopes of approximately $0.2 \mathrm{~s}^{-1} / \mathrm{ppb}$. This indicates increasing model emissions to match observed CDFs would need to be from a source that emits $\mathrm{NO}_{\mathrm{x}}$ and $\mathrm{R}_{\mathrm{OH}}$, VOC in the same proportion as observed. Because biogenic VOC emissions in Fresno are relatively small, this suggests an anthropogenic source that co-emits $\mathrm{NO}_{\mathrm{x}}$ and $\mathrm{VOC}$, including some industrial processes and motor vehicle emissions. Another possibility in the Central Valley is agricultural emissions, which can also emit both $\mathrm{NO}_{\mathrm{x}}$ and VOC. Our simulations do not include agricultural $\mathrm{NO}_{\mathrm{x}}$ emissions, and only traditional biogenic VOC emissions (isoprene and monoterpenes) from crops are included in the biogenic inventory despite knowledge that crops emit a wide variety of biogenic oxygenated VOC (e.g., Kesselmeier and Staudt, 1999).

At Granite Bay (Fig. 4c and g), daytime measured and modeled $\mathrm{NO}_{\mathrm{x}}$ concentrations range from 0-18 ppb and $\mathrm{R}_{\mathrm{OH}, \mathrm{VOC}}$ ranges from $0-15 \mathrm{~s}^{-1}$. Here the model predicts a stronger linear trend of $\mathrm{NO}_{\mathrm{x}}$ and $\mathrm{R}_{\mathrm{OH}, \mathrm{VOC}}$ (slope $=0.43$ and $R^{2}=0.27$ ), while the measurements indicate little to no trend (slope $=0.03$ and $R^{2}=0.01$ ). At Blodgett Forest, $\mathrm{NO}_{\mathrm{x}}$ concentrations are low $(<2 \mathrm{ppb})$ at this site in both the model and the measurements. The model predicts $\mathrm{R}_{\mathrm{OH}, \mathrm{VOC}}$ approximately twice that of the measurements and shows that $\mathrm{R}_{\mathrm{OH}, \mathrm{VOC}}$ and $\mathrm{NO}_{\mathrm{x}}$ are anti-correlated, which is expected at a rural location. Further discussion of these differences is presented in Sects. 3.3 and 3.4 .

\subsection{The diurnal cycle of $\mathrm{R}_{\mathrm{OH} \text {,total }}$}

We next look at the contributions of individual species to

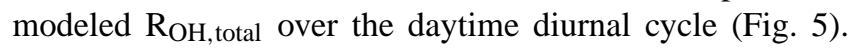
During the daytime, VOC play a dominant role while $\mathrm{NO}_{2}$ loss dominates at night. In the urban locations (Sacramento and Fresno; Fig. 5a and b), the dominant daytime $\mathrm{R}_{\mathrm{OH} \text {,total }}$ is due to anthropogenic VOC and aldehydes. For these two VOC categories, $\mathrm{R}_{\mathrm{OH}}$,total peaks during the early morning rush hour, and a rise in the contribution of the secondary VOC categories (aldehydes and other oxygenated
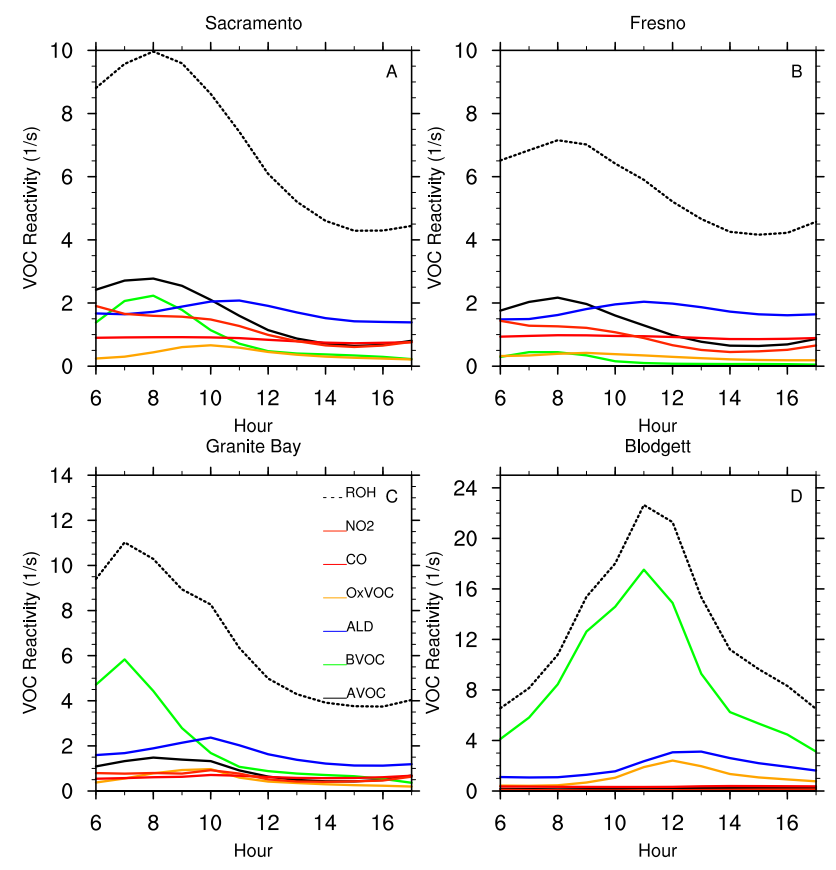

Fig. 5. Average daytime (LT) modeled diurnal cycle of $\mathrm{R}_{\mathrm{OH} \text {,total }}$ (black dashed line) and reactivities of six species at four locations: (a) Sacramento, (b) Fresno, (c) Granite Bay, and (d) Blodgett Forest. Species contributing to $\mathrm{R}_{\mathrm{OH}}$,total include $\mathrm{NO}_{2}$ (brown solid), $\mathrm{CO}$ (red solid), anthropogenic VOC (black solid), biogenic VOC (green solid), aldehydes (blue solid), and other oxygenated VOC (orange solid). $\mathrm{CH}_{4}$ (not shown) contributes a constant value of $0.3 \mathrm{~s}^{-1}$ to $\mathrm{R}_{\mathrm{OH}}$.

VOC species) occurs about an hour or two later. In Sacramento, biogenic VOC play a role equal to aldehydes in the model, while biogenic VOC are of minor importance in Fresno. The remaining three categories $\left(\mathrm{CO}, \mathrm{CH}_{4}\right.$ and other oxygenated VOC) tend to contribute less than $1 \mathrm{~s}^{-1}$ to $\mathrm{R}_{\mathrm{OH}, \text { total }}$.

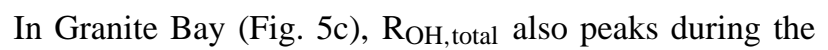
morning rush hour when photochemistry is accelerated, predominantly due to biogenic VOC. Biogenic $\mathrm{R}_{\mathrm{OH}, \mathrm{VOC}}$ also peaks at $6 \mathrm{~s}^{-1}$, a value greater than that of anthropogenic VOC or aldehydes. We note that the model does not reproduce the second diurnal peak in reactivity observed at Granite Bay (Murphy et al., 2006b), and this could be due to the lack of afternoon emissions in the model (discussed below with reference to Fig. 6) or poor representation of mixing and chemistry during the evening boundary layer transition. Additionally, the diurnal cycle of modeled biogenic $\mathrm{R}_{\mathrm{OH}}$, VOC does not reflect the emissions pattern, which peaks at midday due to temperature and radiation patterns. The accuracy of the model related to this peak in biogenic $\mathrm{R}_{\mathrm{OH}, \mathrm{VOC}}$ is discussed in greater detail in the discussion below.

At the rural Blodgett location (Fig. 5d), biogenic VOC dominates the reactivity, leading to a midday peak of 

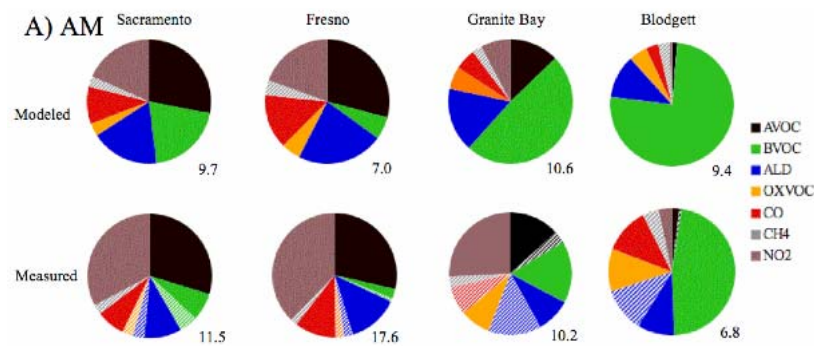

B) $\mathrm{PM}$
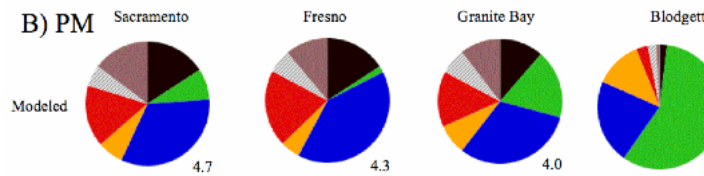

Blodgett

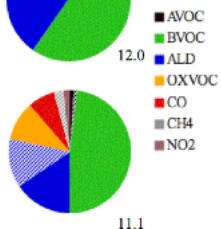

NA

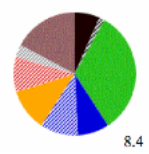

NA

Fig. 6. Modeled and calculated percent contribution to $\mathrm{R}_{\mathrm{OH} \text {,total }}$ $\left(\mathrm{s}^{-1}\right)$ for the four central California locations during (a) morning hours (6-8 a.m. local time) and (b) afternoon hours (1-3 p.m. local time). $\mathrm{R}_{\mathrm{OH}}$,total includes contributions from four VOC categories (anthropogenic, biogenic, aldehydes, and other oxygenated VOC), $\mathrm{CO}, \mathrm{CH}_{4}$ and $\mathrm{NO}_{2}$. Calculated contributions explained in the text and Tables 1 and 2 . $\mathrm{R}_{\mathrm{OH} \text {,total }}$ for each location is noted at the lower right hand of each pie chart. Hatched regions indicate estimated contributions.

$\mathrm{R}_{\mathrm{OH} \text {,total }}=17 \mathrm{~s}^{-1}$, corresponding to the time of maximum biogenic VOC flux. Oxidation products of these biogenic VOC (included in the aldehyde and other oxygenated VOC categories) are the second greatest contributors, reaching a maximum approximately one to two hours after the biogenic

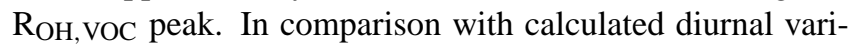
ation in reactivity at Blodgett (Murphy et al., 2006b), the model produces a much stronger midday peak in reactivity $\left(17 \mathrm{~s}^{-1}\right)$ compared to an average afternoon reactivity observed by Murphy et al. (2006b) of $4-5 s^{-1}$. Because the biogenic VOC model is tuned to Blodgett measurements, modeled fluxes of well-characterized biogenic VOC such as methylbutenol compare well with measurements (Steiner et al., 2007), and similar chemical species are included in the measurements and model due to the large amount of data available for Blodgett forest. Therefore, the differences are likely due to errors in the model representation of oxidation rates or mixing rates.

Measurements at the PAMS sites are insufficient to assess

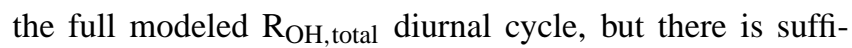
cient data to compare the model and measurements during the morning and afternoon time periods. In some cases, we estimate the contribution of important species that are not included in the measurements. The contribution of $\mathrm{CH}_{4}$

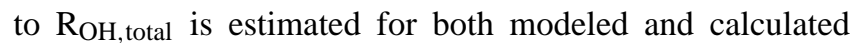
$\mathrm{R}_{\mathrm{OH} \text {,total }}$ based on a concentration of $1800 \mathrm{ppbv}$. For the
PAMS measurement sites (Sacramento and Fresno), the measurements include a large number of anthropogenic hydrocarbons, accounting for many of the reactive species and accounting for a large portion of the modeled lumped anthropogenic categories. However, some important biogenic compounds (terpenes and $\mathrm{MBO}$ ), aldehyde ( $\mathrm{RCHO})$, and other oxygenated VOC that can yield a significant contribution to the total are not measured (see Table 1). For these species, we use model reactivities to estimate their contribution to $\mathrm{R}_{\mathrm{OH} \text {,total }}$, as indicated by the hatched regions of Fig. 6. For Granite Bay and Blodgett, the anthropogenic measurements are not as complete as those provided by the PAMS stations. Therefore, we include model estimates of the top two contributors to anthropogenic $\mathrm{R}_{\mathrm{OH}, \mathrm{VOC}}$ (ethene and ARO2), which are not measured at these locations. We also include model estimates of two important aldehydes (HCHO and $\mathrm{RCHO}$ ), which are unmeasured yet can contribute significantly to $\mathrm{R}_{\mathrm{OH}, \mathrm{VOC}}$. The detailed measurements of biogenic and other oxygenated species at Granite Bay and Blodgett include most of the important reactive species for these two categories (Table 2).

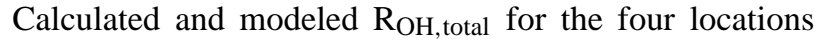
and the relative contributions of individual species are compared at 06:00-08:00 LT (Fig. 6a) and 13:00-15:00 LT (Fig. 6b). The morning time period has the greatest number of VOC measurements, yet also coincides with the earlymorning break up of the atmospheric boundary layer and the strongest anthropogenic emissions, which is when comparison of model and observations is most complicated. In the morning in Sacramento (Fig. 6a), modeled $\mathrm{R}_{\mathrm{OH} \text {,total is about }}$

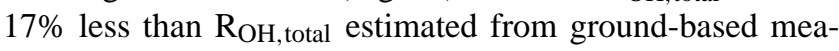
surements. The main difference is due to $\mathrm{NO}_{2}$, where the measurements indicate a contribution of twice that of the

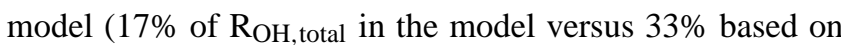
the measurements). As previously discussed, measurement techniques may lead to an overestimate of the calculated

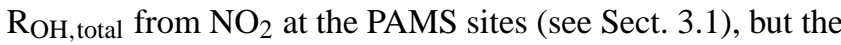
majority of this difference appears to be due to an underestimate of emissions. Calculated (or estimated) and modeled $\mathrm{CH}_{4}$ and $\mathrm{CO}$ compares well and contributes about $3 \%$ and $8 \%$, respectively, to $\mathrm{R}_{\mathrm{OH}}$. For the VOC component, calculated $\mathrm{R}_{\mathrm{OH}}$, VOC is about $60 \%$ of $\mathrm{R}_{\mathrm{OH}}$, total while the model predicts a greater contribution of $70 \%$. Anthropogenic $\mathrm{R}_{\mathrm{OH}, \mathrm{VOC}}$ contributes about $30 \%$ to $\mathrm{R}_{\mathrm{OH}}$,total in both the measurements and the model, indicating that the PAMS measurements of anthropogenic $\mathrm{R}_{\mathrm{OH}}$, VOC are well described by the model at Sacramento in the morning. The discrepancy in $\mathrm{R}_{\mathrm{OH}, \mathrm{VOC}}$ is due to the model predicting a greater contribution of biogenic VOC and aldehydes than are observed. Biogenic $\mathrm{R}_{\mathrm{OH}, \mathrm{VOC}}$ contributes about $20 \%$ to $\mathrm{R}_{\mathrm{OH}}$,total in the model and about $12 \%$ in the measurements, even when including estimates of modeled biogenic VOC species not measured, such as terpenes and MBO. Aldehydes contribute $13 \%$ to calculated $\mathrm{R}_{\mathrm{OH} \text {,total }}$ and $17 \%$ to the modeled $\mathrm{R}_{\mathrm{OH} \text {,total }}$. The minor contribution $(3 \%)$ of the higher order aldehydes estimated from 
the model (RCHO) indicates that the aldehyde measurements at this location ( $\mathrm{HCHO}$ and $\mathrm{CCHO}$ ) are fairly representative of the modeled aldehyde species at this location. Other oxygenated VOC measurements are not available for Sacramento, although they contribute a relatively small fraction in the model (4\%). During the afternoon (Fig. 6b), incomplete measurements do not allow for a comparison, but the modeled $\mathrm{NO}_{2}$ fraction increases along with a decrease in the primary emissions reactivity (anthropogenic and biogenic) and an increase in the secondary VOC reactivity (aldehydes and other oxygenated VOC).

In the morning in Fresno (Fig. 6a), the model underestimates $\mathrm{R}_{\mathrm{OH} \text {,total }}$ by a factor of 2-3 compared to ground-based estimates. A large portion of this difference is due to $\mathrm{NO}_{2}$ and, as in Sacramento, the modeled contribution (18\%) is about half that of the calculated portion (38\%). Calculated and modeled $\mathrm{CO}$ and $\mathrm{CH}_{4}$ also have similar contributions as in Sacramento (11-14\% and 2-3\%, respectively). VOC contributions to $\mathrm{R}_{\mathrm{OH} \text {,total }}$ are about $50 \%$ based on measurements and about $60 \%$ in the model. Anthropogenic VOC contributions to $\mathrm{R}_{\mathrm{OH} \text {,total }}$ are similar in the calculated and modeled results $(\sim 30 \%)$, while the model predicts slightly greater biogenic (6\% modeled vs. $4 \%$ calculated), aldehyde ( $22 \%$ modeled vs. $15 \%$ calculated), and other oxygenated VOC (5\% in the model) contributions. In general, missing measurements of biogenic (terpenes and $\mathrm{MBO}$; green hatched regions) and aldehydes (RCHO; blue hatched regions), as described above, contributed very little to total estimates of biogenic and aldehyde species. Overall in the morning at Fresno, the relative contributions of different types of VOC to $\mathrm{R}_{\mathrm{OH} \text {,total }}$ are similar in the model and observations. This fact coupled with the observation that total reactivity and $\mathrm{NO}_{\mathrm{x}}$ are both low by about the same amount suggests that the model emissions should be substantially increased for both $\mathrm{NO}_{\mathrm{x}}$ and VOC in this region. VOC measurements are not available during the afternoon at Fresno, but similar to Sacramento, the model predicts a smaller contribution of primary VOC reactivity while secondary VOC (aldehydes and other oxygenated VOC) reactivity increases.

Direct measurements of $\mathrm{R}_{\mathrm{OH}}$,total have been performed in several other urban locations in North America. In Nashville,

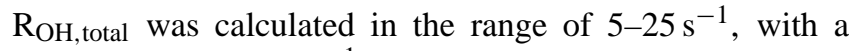
median value of $11 \mathrm{~s}^{-1}$ (Kovacs et al., 2003); measurements range from $15-25 \mathrm{~s}^{-1}$ with a median of $19 \mathrm{~s}^{-1}$ in New York City (Ren et al., 2003). Other studies have estimated $\mathrm{R}_{\mathrm{OH} \text {,total }}$ from $\mathrm{VOC}$ and $\mathrm{NO}_{\mathrm{x}}$ measurements to range from $2-20 \mathrm{~s}^{-1}$ (median $=\sim 4 \mathrm{~s}^{-1}$ ) for Nashville, and $1.5-10 \mathrm{~s}^{-1}$ (median $=\sim 4 \mathrm{~s}^{-1}$ ) for New York City (Kleinman

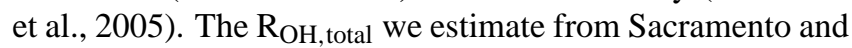
Fresno $\left(6-20 \mathrm{~s}^{-1}\right)$ are consistent with those of other urban areas in the United States.

At Granite Bay (Fig. 6a), the calculated $\left(10.6 \mathrm{~s}^{-1}\right)$ and modeled $\left(10.2 \mathrm{~s}^{-1}\right)$ morning $\mathrm{R}_{\mathrm{OH} \text {,total }}$ is very similar. As with Sacramento and Fresno, however, the model predicts a

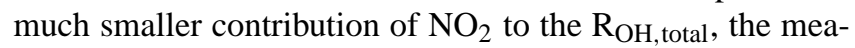

surements show that the $\mathrm{R}_{\mathrm{OH} \text {,total }}$ due to $\mathrm{NO}_{2}$ is $2.6 \mathrm{~s}^{-1}$ while the model calculates $0.8 \mathrm{~s}^{-1}$. Anthropogenic VOC components agree well in the morning (about $16 \%$ in the measurements and $13 \%$ in the model), and including additional anthropogenic VOC (black hatched regions) does not make a significant impact on $\mathrm{R}_{\mathrm{OH}, \mathrm{VOC}}$. The model predicts a greater fraction of the total reactivity is biogenic VOC, $\sim 50 \%$ compared to the $20 \%$ in the measurements. This suggests that the morning biogenic VOC reactivity is much larger than that observed. Calculated and modeled aldehyde reactivities are similar, contributing about $23 \%$ and $17 \%$ to $\mathrm{R}_{\mathrm{OH}}$, respectively. Calculated CCHO reactivity at Granite Bay is greater than that predicted by the model, leading to a greater aldehyde reactivity based on measurements. In the afternoon at Granite Bay (Fig. 6b), the model predicts $\mathrm{R}_{\mathrm{OH} \text {,total }}$ that is a factor of two smaller than the measurements. The greatest discrepancies for the calculated and modeled reactivities at Granite Bay can be attributed to $\mathrm{NO}_{2}$, biogenic VOC, and aldehyde components. Again $\mathrm{NO}_{2}$ is underestimated, although not as significantly as in the morning hours. Aldehyde chemistry in the model tends to follow the changes in anthropogenic and biogenic reactivity (increases as the anthropogenic and biogenic reactivity decreases), but this is not reflected in the measurements. The model predicts more biogenic reactivity than aldehyde $\mathrm{R}_{\mathrm{OH}, \mathrm{VOC}}$ in the morning, while the measurements indicate that aldehyde $\mathrm{R}_{\mathrm{OH}} \mathrm{VOC}$ dominates over biogenic $\mathrm{R}_{\mathrm{OH}} \mathrm{VOC}$.

At Blodgett Forest in the morning (Fig. 6a), calculated

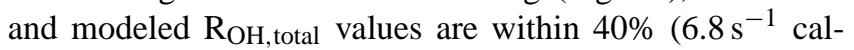
culated, $9.4 \mathrm{~s}^{-1}$ modeled). Contributions from $\mathrm{NO}_{2}(1-3 \%)$, $\mathrm{CO}(4-12 \%)$, and $\mathrm{CH}_{4}(3-4 \%)$ are small compared to that from VOC, which contribute about $80 \%$ based on measurements and $90 \%$ in the model. Anthropogenic VOC plays a small role in $\mathrm{R}_{\mathrm{OH} \text {,total }}(2-3 \%)$. At Blodgett, the differ-

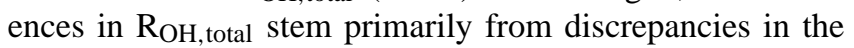
biogenic category. The model predicts about $75 \%$ of the $\mathrm{R}_{\mathrm{OH} \text {,total }}$ is due to biogenic VOC in the morning, while the measurements show this fraction is about $50 \%$. In the afternoon (Fig. 5b), calculated and modeled $\mathrm{R}_{\mathrm{OH}}$,total and relative VOC contributions are within $10 \%$ of each other, again with an overestimate of biogenic reactivity in the model compared to observations. One possible reason for this difference could be due to the biogenic emissions model, which predicts primary isoprene fluxes from Blodgett forest that are not observed at the site. These emissions, which are nearly equal to MBO emissions, could be contributing to the higher reactivity in the model. Another possibility is that fast chemistry within the forest canopy could react away many of the highly reactive terpenes and this fast chemistry cannot be reproduced by the model. Both of these factors could contribute to the over prediction of modeled $\mathrm{R}_{\mathrm{OH}, \mathrm{VOC}}$.

To summarize, the urban reactivity comparison suggests $\mathrm{VOC}$ and $\mathrm{NO}_{\mathrm{x}}$ emissions are underestimated in the model, yet the relative proportions of the various reactivity sources to $\mathrm{R}_{\mathrm{OH} \text {,total }}$ are approximately correct. Analysis of the mod- 

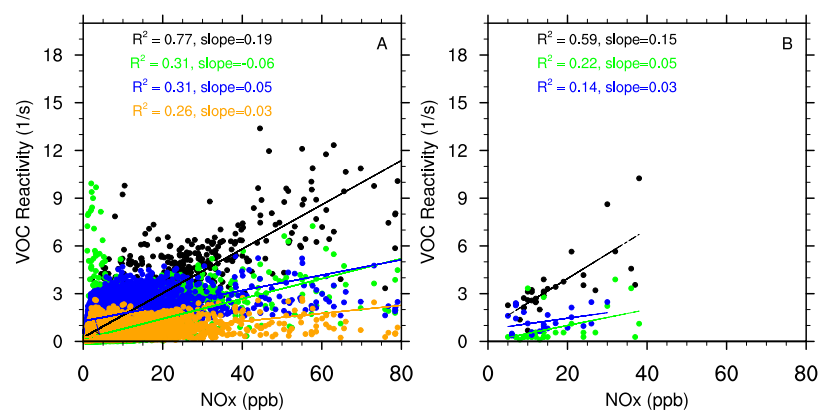

Fig. 7. Speciated $\mathrm{R}_{\mathrm{OH}}$, VOC $\left(\mathrm{s}^{-1}\right)$ as a function of $\mathrm{NO}_{\mathrm{x}}$ concentrations (ppb) in Sacramento, as (a) modeled and (b) calculated. The contribution of the four VOC categories to the $\mathrm{R}_{\mathrm{OH}, \mathrm{VOC}}$, including anthropogenic VOC (black), biogenic VOC (green), aldehydes (blue), and other oxygenated VOC (orange). For the calculated Sacramento $\mathrm{R}_{\mathrm{OH}, \mathrm{VOC}}$, biogenic $\mathrm{R}_{\mathrm{OH} \text {,VOC }}$ is based on isoprene concentrations only, and aldehydes are based on $\mathrm{HCHO}$ and CCHO concentrations only. See Table 1 for a full list of VOC species included in each category.

eled and observed VOC contributions to $\mathrm{R}_{\mathrm{OH} \text {,total }}$ in the two urban locations show that $\mathrm{NO}_{2}$ and anthropogenic VOC are the two largest factors. The main categories of VOC contribution to $\mathrm{R}_{\mathrm{OH} \text {,total }}$ in urban areas are anthropogenic $\mathrm{VOC}$ ( $28 \%$ ), followed by aldehydes (17-22\%), biogenic VOC (6-20\%), and other oxygenated VOC (4-6\%). Modeled biogenic VOC contribute more to $\mathrm{OH}$ reactivity in Sacramento $(20 \%)$ than Fresno (6\%), and this is reflected in the measurements.

At Granite Bay, the model and measurements agree well

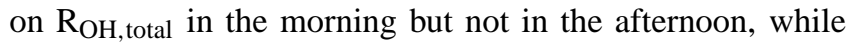
the opposite is true at Blodgett Forest. In both locations, the discrepancies are due to the relative contributions of aldehydes and biogenic VOC. At Granite Bay, modeled biogenic VOC is greater than calculated in the morning, but the converse is true in the afternoon. At Blodgett Forest, the model consistently predicts greater biogenic VOC than that calculated from measurements. These differences are indicative of errors in chemistry, as we have shown the emissions are consistent with observations.

\subsection{The relationship between speciated $\mathrm{R}_{\mathrm{OH}, \mathrm{VOC}}$ and $\mathrm{NO}_{\mathrm{x}}$}

More insight into where the model is accurately describing the relationships between $\mathrm{NO}_{\mathrm{x}}$ and VOC reactivity can be found by comparing each of the four VOC categories versus $\mathrm{NO}_{\mathrm{x}}$ (Fig. 7). In the urban locations, we expect that anthropogenic VOC and $\mathrm{NO}_{\mathrm{x}}$ will be positively correlated, as both emissions have primary sources from transportation and chemical removal largely occurs downwind. In Sacramento, the slopes of correlation of anthropogenic VOC reactivity with $\mathrm{NO}_{\mathrm{x}}$ are $0.15 \mathrm{~s}^{-1} / \mathrm{ppb} \mathrm{NO}_{\mathrm{x}}$ for the observations and $0.19 \mathrm{~s}^{-1} / \mathrm{ppb} \mathrm{NO}_{\mathrm{x}}$ for the model. We note that some of the difference in slope could be due to the positive bias in the
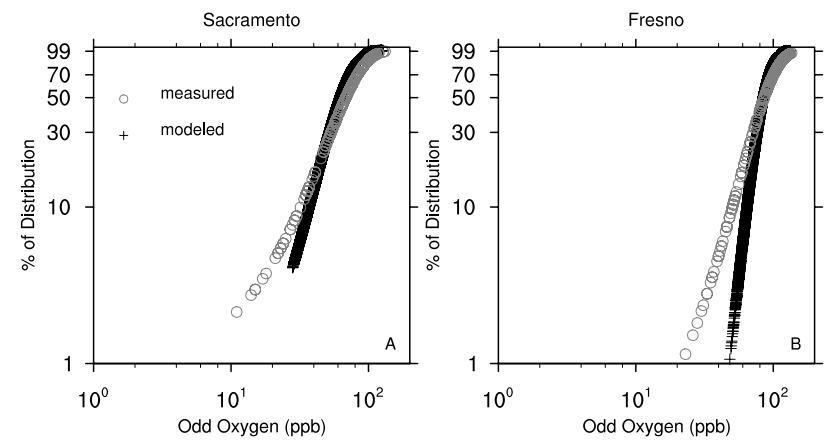

Fig. 8. Measured (gray circles) versus modeled (black crosses) cumulative distribution functions for (a) Sacramento odd oxygen $\left(\mathrm{O}_{3}+\mathrm{NO}_{2}\right)$ and (b) Fresno odd oxygen. Ozone and $\mathrm{NO}_{2}$ data from PAMS stations represents daytime data during the time period of the simulation $(29 / 07 / 2000-03 / 08 / 2000)$.

PAMS $\mathrm{NO}_{2}$ as discussed in Sect. 3.1. There are no significant correlations of $\mathrm{NO}_{\mathrm{x}}$ and the other categories of VOC in the observations or the model.

\subsection{Implications for ozone chemistry}

Based on the above comparisons between measured and modeled urban chemistry, the under estimation of $\mathrm{NO}_{\mathrm{x}}$ and VOC emissions inventories are notable and likely have implications for ozone prediction in central California. Our prior central California ozone study (Steiner et al., 2006) compared modeled afternoon ozone concentrations versus ground-based observations, and found that the near-surface ozone daily maxima were reproduced by in the model in the central Valley. In the Sacramento region, however, modeled ozone maximum concentrations were about 10-20 ppb less than those observed, and this discrepancy was attributed to poor meteorological representation of upslope flow along the Sierra. In Fresno, measured concentrations of ozone show similar maxima to those modeled (90-100 ppb). Results from this study indicate that inaccurate emissions inventories could also contribute to these differences in ozone concentrations.

In both Sacramento and Fresno, we compare measured and modeled odd oxygen $\left(\mathrm{O}_{3}+\mathrm{NO}_{2}\right)$ (Fig. 8). During the simulation time period, the model roughly captures the median of odd oxygen in both Sacramento and Fresno. However, the model over predicts the lower $10 \%$ of the distribution in both locations by about $5 \mathrm{ppb}$, and under estimates the top $10 \%$ by about $10-20 \mathrm{ppb}$. This behavior is not supported by the distribution functions of $\mathrm{NO}_{\mathrm{x}}$ concentrations and $\mathrm{NO}_{\mathrm{x}}$ and VOC reactivity (Fig. 2), which indicated that emissions were under predicted by the model at these locations over most of the distribution. This suggests that other factors are important for local ozone, including the mixing depths, large-scale meteorology, and the transport of ozone formed in other urban areas such as San Francisco. Because these distributions 
are based on ozone concentrations and not local ozone production, it is impossible to discern the difference between locally produced and transported ozone at this time. However, this does suggest that merely increasing $\mathrm{NO}_{\mathrm{x}}$ and VOC emissions to address the emission estimate discrepancies may not improve ozone prediction in central California.

\subsection{Present day and future spatial distributions of $\mathrm{R}_{\mathrm{OH}, \mathrm{VOC}}$}

Over the model domain, $\mathrm{R}_{\mathrm{OH}, \mathrm{VOC}}$ reaches up to $16 \mathrm{~s}^{-1}$ in the morning hours and is greatest near urban areas and regions with high biogenic VOC emissions (Fig. 9a). $\mathrm{R}_{\mathrm{OH}, \mathrm{VOC}}$ outside regions with high anthropogenic and biogenic VOC emissions tend to be low $\left(<4 \mathrm{~s}^{-1}\right)$. The contribution of each VOC category to total modeled reactivity varies with emissions geography. Anthropogenic and biogenic VOC reactivities are located near emission sources (Fig. $9 \mathrm{~b}$ and c), with anthropogenic $\mathrm{R}_{\mathrm{OH}, \mathrm{VOC}}$ occurring near urban centers and biogenic $\mathrm{R}_{\mathrm{OH}, \mathrm{VOC}}$ dominating in the mountainous and vegetated regions of the domain. However, an interesting point in this simulation is the importance of aldehyde and other oxygenated species with respect to $\mathrm{R}_{\mathrm{OH}, \mathrm{VOC}}$ throughout the model domain (Fig. 9d). Overall, the aldehyde and other oxygenated $\mathrm{R}_{\mathrm{OH}, \mathrm{VOC}}$ accounts for at least $40 \%$ of $\mathrm{R}_{\mathrm{OH}, \mathrm{VOC}}$. In agricultural regions of the Central Valley, where measurements are unavailable, the oxygenated VOC fraction represents up to $90 \%$ of total reactivity with minor contributions from primary anthropogenic and biogenic emissions. As shown in Figs. 5 and 6, the model indicates that alde-

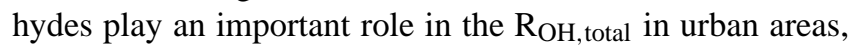
accounting for $30-40 \%$ of $\mathrm{R}_{\mathrm{OH} \text {,total }}$ in the afternoon. This indicates that aldehyde compounds produced by secondary formation in the atmosphere play a significant role in the cycling of $\mathrm{HO}_{\mathrm{x}}$ in all regions, even those with of high primary emissions of anthropogenic and biogenic VOC.

For the climate change simulation described in Sect. 2, we examine changes in $\mathrm{R}_{\mathrm{OH}, \mathrm{VOC}}$ under future climate conditions. Warmer temperatures and a moister atmosphere can alter photochemical reaction rates and VOC emission profiles, affecting total and speciated reactivities in the region. The change in morning average $\mathrm{R}_{\mathrm{OH} \text {,total }}$ is almost completely composed of $\mathrm{R}_{\mathrm{OH}, \mathrm{VOC}}$, which increases over almost all land points in the model domain (Fig. 9e). The largest increases in $\mathrm{R}_{\mathrm{OH}, \mathrm{VOC}}$ occur in the Sierra Nevada Mountains, where $\mathrm{R}_{\mathrm{OH}, \mathrm{VOC}}$ increases up to $5 \mathrm{~s}^{-1}(\sim 33 \%)$ due to an increase in biogenic VOC emissions (Fig. 9g) and subsequent reactions (Fig. 9h). In urban areas such as the eastern portion of the San Francisco Bay area, $\mathrm{R}_{\mathrm{OH}, \mathrm{VOC}}$ increases by about $1-2 \mathrm{~s}^{-1}(12-15 \%)$.

In regions of high reactivity, the increase in $\mathrm{R}_{\mathrm{OH}, \mathrm{VOC}}$ is due to an increase in biogenic, aldehyde and other oxygenated reactivities. We note that the magnitude of these changes should be considered in light of our previous results in Sect. 3, which indicate that the model is predicting more biogenic and aldehyde VOC reactivity than that esti-
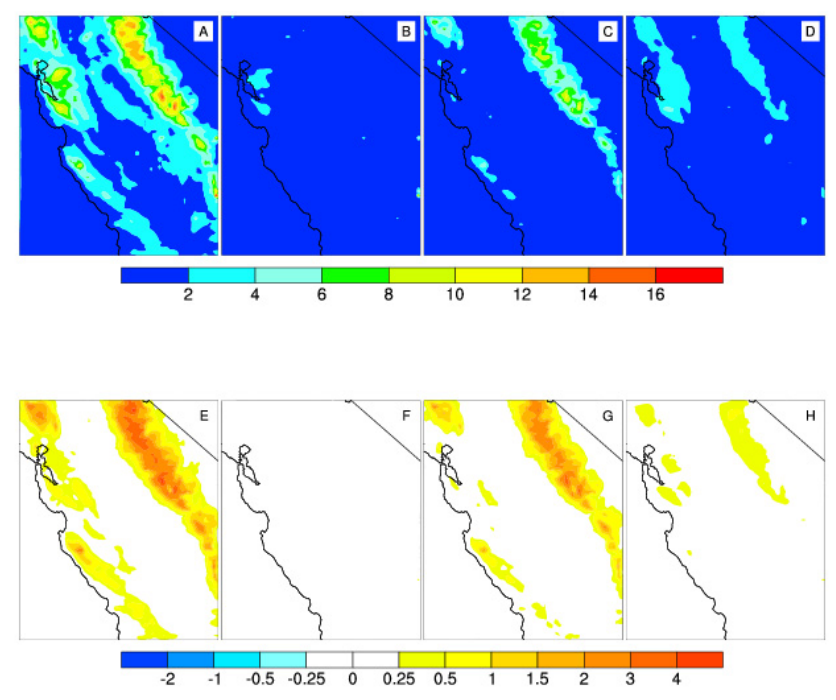

Fig. 9. Present-day and future morning reactivity $\left(s^{-1}\right)$. Top panel is present-day reactivity for (a) $\mathrm{R}_{\mathrm{OH}, \mathrm{VOC}}$, including four VOC categories (anthropogenic, biogenic, aldehydes, and other oxygenated VOC) and (b) anthropogenic VOC, (c) biogenic VOC, (d) aldehydes. Bottom panel is the change to reactivity under future climate conditions for (e) $\mathrm{R}_{\mathrm{OH}, \mathrm{VOC}}$, (f) anthropogenic VOC, (g) biogenic VOC and (h) aldehydes. Positive values reflect an increase in total reactivity under future climate.

mated from ground-based measurements. However, despite uncertainties in model reactivities, these results indicate that climate impacts on anthropogenic VOC chemistry are small compared to impacts on biogenic, aldehyde and other oxygenated VOC species. Additionally, in urban areas with significant biogenic VOC, changes in biogenic emissions will likely have more impact on $\mathrm{R}_{\mathrm{OH}, \mathrm{VOC}}$ than anthropogenic species. If anthropogenic emissions were to change in a future emissions scenario, then the relative impact of their reactivity will likely change as well.

\section{Conclusions and implications}

Comparisons of calculated and modeled $\mathrm{R}_{\mathrm{OH} \text {,total and }}$ $\mathrm{R}_{\mathrm{OH}, \mathrm{VOC}}$ indicate that the model generally predicts $\mathrm{R}_{\mathrm{OH} \text {,total }}$ within 25-40\% of the observations at three of the four locations (Sacramento, Granite Bay and Blodgett Forest). At the fourth location, Fresno, the model under predicts both $\mathrm{NO}_{\mathrm{x}}$ and $\mathrm{R}_{\mathrm{OH}, \mathrm{VOC}}$ emissions by a factor or $2-3$. At Sacramento and Fresno, we suspect that the $\mathrm{R}_{\mathrm{OH}}$,total differences are in part due to the inadequacies of current $\mathrm{NO}_{2}$ measurements used in regulatory networks, which can overestimate $\mathrm{NO}_{2}$ and hence $\mathrm{R}_{\mathrm{OH} \text {,total }}$ substantially (e.g., Dunlea et al., 2007). Because meteorological parameters such as boundary layer height, and wind speeds and directions are represented fairly well during the simulation time period (Wilczak et al., 2004), the representation of the measured and mod- 
eled cumulative distribution functions indicate that the emissions inventory in urban locations underestimates both $\mathrm{NO}_{\mathrm{x}}$ and anthropogenic VOC emissions. This result is consistent with other studies that indicate that emission inventories are underestimated with respect to on-road emissions (Parrish, 2006; Warneke et al., 2007). Despite these apparent under estimates of ozone precursors, the model predicts a cumulative distribution function for ozone that is similar to the measurements, indicating that simply increasing emissions will likely not improve ozone predictions. Suburban and rural locations show slightly better agreement, likely in part due to direct measurements of $\mathrm{NO}_{2}$ and in part to the reduced importance of anthropogenic emissions inventories.

The fraction of $\mathrm{R}_{\mathrm{OH} \text {,total }}$ from VOC is well-represented at all four locations in central California. The model captures the relative relationships between anthropogenic, biogenic, aldehyde and other oxygenated $\mathrm{R}_{\mathrm{OH}, \mathrm{VOC}}$ with $\mathrm{NO}_{\mathrm{x}}$, however some locations have notable exceptions. In urban areas, anthropogenic and biogenic $\mathrm{R}_{\mathrm{OH}, \mathrm{VOC}}$ are predicted reasonably over a range of $\mathrm{NO}_{\mathrm{x}}$ conditions. In suburban and rural locations, anthropogenic, aldehyde and other oxygenated $\mathrm{R}_{\mathrm{OH}, \mathrm{VOC}}$ relationships are reproduced, but biogenic $\mathrm{R}_{\mathrm{OH}, \mathrm{VOC}}$ is difficult to emulate, and this may be due to improperly modeled chemical mixing and reactions in the atmospheric boundary layer. Aldehydes make a significant contribution to modeled $\mathrm{R}_{\mathrm{OH}, \mathrm{VOC}}$ at all locations, but are difficult to validate based on the limited number of oxygenated VOC measurements.

Under predicted future climate conditions, higher temperatures will affect physical and chemical properties of the atmosphere, increasing $\mathrm{R}_{\mathrm{OH}, \mathrm{VOC}}$ over the model domain about $30 \%$ near regions of increased biogenic VOC emissions. Our results indicate that biogenic and oxygenated VOC will continue to contribute to radical and ozone production in the future in California, and these impacts will be greatest in the regions where biogenic emissions increase due to increasing temperature. This indicates that anthropogenic VOC control may be less effective in some regions under future scenarios, although this is strongly dependent on the fate of future anthropogenic VOC emissions.

We find that oxygenated VOC play an important role in VOC reactivity throughout central California. Other studies

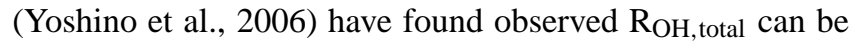
greater than modeled $\mathrm{R}_{\mathrm{OH}}$, and that this missing $\mathrm{OH}$ sink may be due to reaction with oxygenated VOC. In the Bay Area, up to $50 \%$ of the modeled $\mathrm{R}_{\mathrm{OH}, \mathrm{VOC}}$ is due to oxygenated species and this amplifies local $\mathrm{HO}_{\mathrm{x}}$ production cycles. Oxygenated compounds dominate $\mathrm{R}_{\mathrm{OH}, \mathrm{VOC}}$ in the San Joaquin Valley, where primary emissions of anthropogenic and oxygenated species are currently estimated to be low. However, emissions of aldehydes and other oxygenated VOC are currently not well quantified from either anthropogenic or biogenic sources. Detailed anthropogenic and biogenic oxygenated VOC emission inventories could improve the emission inputs to regional air quality models. These compounds are often not measured as part of ground-based measurement campaigns, and they are needed to verify emission inventories, reactivity in the atmosphere, and impacts on gas and particle phase chemistry. More measurements of a suite of oxygenated VOC would provide an additional means of assessing their importance in regional chemistry under present and future climate conditions.

Acknowledgements. This work has been funded by a grant from the U.S. Environmental Protection Agency's Science to Achieve Results (STAR) program. Although the research described in this article has been funded wholly or in part by the U.S. Environmental Protection Agency through grant RD-83096401-0 to the University of California, Berkeley, it has not been subjected to the Agency's required peer and policy review and therefore does not necessarily reflect the view of the Agency and no official endorsement should be inferred. We thank J. Murphy for helpful comments on this manuscript.

Edited by: J. Rinne

\section{References}

Atkinson, R.: Gas-phase tropospheric chemistry of organic compounds, J. Phys. Chem. Ref. Data Monograph, 2, 1, 1994.

Atkinson, R.: Atmospheric Chemistry of VOCs and $\mathrm{NO}_{\mathrm{x}}$, Atmos. Environ., 34, 2063-2101, 2000.

Atkinson, R., Aschmann, S. M., Arey, J., and Carter, W .P. L: Formation of 3-methylfuran from the gas-phase reaction of $\mathrm{OH}$ radicals with isoprene and the rate constant for it reaction with the OH radical, Int. J. Chem. Kinetics, 21, 593-604, 1989.

Avery, R. J.: Reactivity-based VOC control for solvent products: More efficient ozone reduction strategies, Environ. Sci. Technol., 40, 4845-4850, 2006.

Blanchard, C. L. and Fairley, D.: Spatial mapping of VOC and $\mathrm{NO}_{\mathrm{x}}$ -limitation of ozone formation in central California, Atmos. Environ. 35, 3861-3873, 2001.

Byun, D. W. and Ching, J. K. S: Science algorithms of the EPA Models-3 Community Multiscale Air Quality (CMAQ) modeling system, EPA/600/R-99/030, USEPA, 1999.

Cardelino, C. A. and Chameides, W. L.: Natural hydrocarbons, urbanization, and urban ozone, J. Geophys. Res., 95, 1397113 979, 1990.

Carter, W. P. L.: Development of ozone reactivity scales for volatile organic compounds, J. Air Waste Manag. Assoc., 44, 881-899, 1994.

Carter, W. P. L.: Implementation of the SAPRC-99 Chemical Mechanism into the Models-3 Framework, Report to the US Environmental Protection Agency, 2000.

Cleary, P. A., Wooldridge, P. J., and Cohen, R. C: Laser-induced Fluorescence Detection of Atmospheric $\mathrm{NO}_{2}$ Using a Commercial Diode Laser and a Supersonic Expansion, Appl. Opt., 41(33), 6950-6956, 2002.

Cleary, P. A., Wooldridge, P. J., Day, D. A., Millet, D., McKay, M., Goldstein, A. H., and Cohen, R. C.: Observations of Total Alkyl nitrates within the Sacramento Urban Plume, Atmos. Chem. Phys. Discuss., 5, 4801-4843, 2005, http://www.atmos-chem-phys-discuss.net/5/4801/2005/. 
Choi, Y.-J., Calbrese, R. V., Ehrman, S. H., Dickerson, R. R., and Stehr, J. W.: A combined approach for the evaluation of a volatile organic compound emissions inventory, J. Air Waste Mange. Assoc., 56, 169-178, 2006.

Day, D. A., Dillon, M. B., Wooldridge, P. J., Thornton, J. A., Rosen, R. S., Wood, E. C., and Cohen, R. C.: On Alkyl Nitrates, Ozone and the 'Missing $\mathrm{NO}_{\mathrm{y}}$ ', J. Geophys. Res., 108(D16), 4501, doi:10.1029/2003JD003685, 2003.

Day, D. A., Wooldridge, P. J., and Cohen, R. C.: Observations of the effects of temperature on atmospheric $\mathrm{HNO}_{3}, \Sigma$ ANs, $\Sigma$ PNs and $\mathrm{NO}_{\mathrm{X}}$ : Evidence for a temperature dependent $\mathrm{HO}_{\mathrm{X}}$ source, Atmos. Phys. Chem. Discuss., 11 091-11 121, 2007.

Dickson, R. J., Wilkinson, J. G., Bruckman, L., and Tesche, T. W.: Conceptual formation of the emissions modeling system, in: Planning and Managing Regional Air Quality: Modeling and Measurement Studies, edited by: Solomon, P. A., CRC Press, Boco Raton, FL, 79-106, 1994.

Dunlea, E. J., Herndon, S. C., Nelson, D. D., Volkamer, R. M., San Martini, F., Sheehy, P. M., Zahniser, M. S., Shorter, J. H., Wormhoudt, J. C., Lamb, B. K., Allwine, E. J., Gaffney, J. S., Marley, N. A., Grutter, M., Marquez, C., Blanco, S., Cardenas, B., Retama, A., Ramos Villegas, C. R., Kolb, C. E., Molina, L. T., and Molina, M. J.: Evaluation of nitrogen dioxide chemiluminescence monitors in a polluted urban environment, Atmos. Chem. Phys., 7, 2691-2704, 2007,

http://www.atmos-chem-phys.net/7/2691/2007/.

Ervens, B., Feingold, G., Frost, G. J., and Kreidenweis, S. M.: A modeling study of aqueous production of dicarboxylic acids: 1 . Chemical pathways and speciated organic mass production, J. Geophys. Res., 109, D15205, doi:10.1029/2003JD004387, 2004.

Han, Z., Ueda, H., and Matsuda, K.: Model study of the impact of biogenic emission on regional ozone and the effectiveness of emission reduction scenarios over eastern China, Tellus, 57B, 12-27, 2005.

Harley, R. A., Marr, L. C., Lehner, J. K., and Giddings, S. N.: Changes in motor vehicle emissions on diurnal to decadal time scales and effects on atmospheric composition, Environ. Sci. Technol., 39, 5356-5362, 2005.

Jiang, G. and Fast, J. D: Modeling the effects of VOC and NOx emission sources on ozone formation in Houston during the TexAQS 2000 field campaign, Atmos. Environ., 38, 5071-5085, 2004.

Kalberer, M., Paulsen, D., Sax, M., et al.: Identification of polymers as major components of atmospheric organic aerosols, Science, 303, 5664, 1659-1662, 2004.

Kesselmeier, J. and Staudt, M.: Biogenic volatile organic compounds (VOC): An overview on emission, physiology and ecology, J. Atmos. Chem., 33, 23-88, 1999.

Kleinman, L. I., Daum, P. H., Lee, Y.-N., et al.: A comparative study of ozone production in five U.S. metropolitan areas, J. Geophys. Res., 110, D02301, doi:10.1029/2004JD004096, 2005.

Kovacs, T. A., Brune, W., Harder, H., et al.: Direct measurements of urban OH reactivity during Nashville SOS in summer 1999, J. Environ. Monit., 5, 68-74, 2003.

Kwok, E. S. C. and Atkinson, R.: Estimation of hydroxyl radical reaction rate constants for gas-phase organic compounds using structure-reactivity relationships - An update, Atmos. Environ., 29, 1685-1695, 1995.

Lamanna, M. S. and Goldstein, A. H.: In-situ measurements of C2-
C10 VOCs above a Sierra Nevada ponderosa pine plantation, J. Geophys. Res., 104(D17), 21 247-21 262, 1999.

Marr, L. C.: Changes in ozone sensitivity to precursor emissions on diurnal, weekly and decadal time scales, Ph.D. thesis, University of California, Berkeley, 213 pp., 2002.

Marr, L. C., Black, D. R., and Harley, R. A.: Formation of photochemical air pollution in Central California. I. Development of a revised motor vehicle emission inventory, J. Geophys. Res., 107(D6) 4047, doi:10.1029/2001JD000689, 2002.

Marr, L. C. and Harley, R. A.: Modeling the effect of weekdayweekend differences in motor vehicle emissions on photochemical air pollution in Central California, Environ. Sci. Technol., 26, 4099-4106, 2002.

Martien, P. T. and Harley, R. A.: Adjoint Sensitivity Analysis for a Three-Dimensional Photochemical Model: Application to Southern California, Environ. Sci. Technol., 40, 4200-4210, 2006.

McClenny, W. A., Oliver, K. D., Jacumin Jr., H. H., Daughtrey Jr., E. H.: Ambient level volatile organic compound (VOC) monitoring using solid adsorbents - Recent US EPA studies, J. Environ. Monit., 4, 695-705, 2002.

Milford, J. B., Russell, A. G. and McRae, G. J.: A new approach to photochemical pollution control: Implications of spatial patterns in pollutant responses to reductions in nitrogen oxides and reactive organic gas emissions, Environ. Sci. Technol., 23, 12901301, 1989.

Millet, D. B., Donahue, N. M., Pandis, S. N., Polidori, A., Stanier, C. O., Turpin, B. J., and Goldstein, A. H.: Atmospheric volatile organic compound measurements during the Pittsburgh Air Quality Study: Results, interpretation and quantification of primary and secondary contributions, J. Geophys. Res., 110, D07S07, doi:10.1029/2004JD004601, 2005.

Murphy, J. G., Day, D. A., Cleary, P. A., Wooldridge, P. J., Millet, D. B., Goldstein, A. H., and Cohen, R. C.: The weekend effect within and downwind of Sacramento: Part 1. Observations of ozone, nitrogen oxides, and VOC reactivity, Atmos. Chem. Phys., 7, 5327-5339, 2007,

http://www.atmos-chem-phys.net/7/5327/2007/.

Murphy, J. G., Day, D. A., Cleary, P. A., Wooldridge, P. J., Millet, D. B., Goldstein, A. H., and Cohen, R. C.: The weekend effect within and downwind of Sacramento: Part 2. Observational evidence for chemical and dynamical contributions, Atmos. Chem. Phys. Discuss., 6, 11 971-12019, 2006b.

National Research Council: Rethinking the ozone problem in urban and regional air pollution, The National Academy Press, Washington D.C., 1991.

Odum, J. R., Jungkamp, T. P. W., Griffin, R. J., et al.: The atmospheric aerosol-forming potential of whole gasoline vapor, Science, 276, 96-99, 1997.

Papagni, C., Arey, J., and Atkinson, R.: Rate constants for the gasphase reactions of a series of C3-C6 aldehydes with $\mathrm{OH}$ and NO3 radicals, Int. J. Chem. Kinetics, 32, 79-84, 2000.

Parrish, D. D.: Critical evaluation of US on-road vehicle emission inventories, Atmos. Environ., 40, 2288-2300, 2006.

Ren, X., Harder, H., Martinez, M., et al.: $\mathrm{HO}_{\mathrm{x}}$ concentrations and $\mathrm{OH}$ reactivity observations in New York City during PMTACSNY2001, Atmos. Environ., 37, 3627-3637, 2003.

Russell, A. G., Milford, J., Bergin, M. S., et al.: Urban ozone control and atmospheric reactivity of organic gases, Science 269 , 
491-495, 1995.

Schade, G. W. and Goldstein, A. H.: Fluxes of oxygenated volatile organic compounds from a ponderosa pine plantation, J. Geophy. Res., 106(D3), 3111-3123, 2001.

Scott, K. I. and Benjamin, M. T.: Development of a biogenic volatile organic compound emission inventory for the SCOS97NARSTO domain, Atmos. Environ., 37(2), S39-S49, 2003.

Sillman, S., Logan, J. A., and Wofsy, S. C.: The sensitivity of ozone to nitrogen oxides and hydrocarbons in regional ozone episodes, J. Geophys. Res., 95, 1837-1851, 1990.

Snyder, M. A., Bell, J. L., Sloan, L. C., Duffy, P. B., and Govindasamy, B.: Climate responses to a doubling of atmospheric carbon dioxide for a climatically vulnerable region, Geophys. Res. Lett., 29, 11, doi:10.1029/2001GL014431, 2002

Steinbacher, M., Zellweger, C., Schwarzenbach, B., Bugmann, S., Buchmann, B., Ordonez, C., Prevot, A. S. H., and Hueglin, C.: Nitrogen oxide measurements at rural sites in Switzerland: Bias of conventional measurement techniques, J. Geophys. Res., 112, D11307, doi:10.1029/2006JD007971, 2007.

Steiner, A. L., Tonse, S., Cohen, R. C., Goldstein, A. H., and Harley, R. A.: Influence of future climate and emissions on regional air quality in California, J. Geophys. Res., 111, D18303, doi:10.1029/2005JD006935, 2006.

Steiner, A. L., Tonse, S., Cohen, R. C., Goldstein, A. H., and Harley, R. A.: Biogenic 2-methyl-3-buten-2-ol increases regional ozone and HOx sources, Geophys. Res. Lett., 34, L15806, doi:10.1029/2007GL030802, 2007.

Thornton, J. A., Wooldridge, P. J., and Cohen, R. C.: Atmospheric NO2: In Situ Laser-Induced Fluorescence Detection at Parts per Trillion Mixing Ratios, Anal. Chem., 72, 528-539, 2000.
Trainer, M., Williams, E. T., Parrish, D. D., Buhr, M. P., Allwine, E. J., Westberg, H. H., Fehsenfeld, F. C., and Liu, S. C. : Models and observations of the impact of natural hydrocarbons on rural ozonem Naturem 329, 705-707, 1987.

Velasco, E., Lamb, B., Westberg, H., et al.: Distribution, magnitudes, reactivities, ratios and diurnal patterns of volatile organic compounds in the Valley of Mexico during MCMA 2002 \& 2003 field campaigns, Atmos. Chem. Phys., 7, 329-353, 2007, http://www.atmos-chem-phys.net/7/329/2007/.

Warneke, C., McKeen, S. A., de Gouw, J. A., et al.: Determination of urban volatile organic compound emission ratios and comparisons with an emissions database, J. Geophys. Res., 112, D10S47, doi:10.1029/2006JD007930, 2007.

Wilczak, J. M., Bao, J.-W., Michelson, S. A., Tanrikulu, S., and Soong, S.-T.: Simulation of an ozone episode during the Central California Ozone Study, Part I: MM5 meteorological model simulations, 13th Conf. on the Applications of Air Pollution Meteorology with the Air and Waste Management Association, Vancouver, B.C., 2004.

Winer, A. M., Peters, J. W., Smith, J. P., and Pitts Jr., J. N.: Response of commercial chemiluminescent $\mathrm{NO}-\mathrm{NO}_{2}$ analyzers to other nitrogen-containing compounds, Environ. Sci. Technol, 8(13), 1118-1121 1974.

Yoshino, A., Sadanaga, Y., Watanabe, K., et al.: Measurement of total $\mathrm{OH}$ reactivity by laser-induced pump and probe technique comprehensive observations in the urban atmosphere of Tokyo, Atmos. Environ., 40, 7869-7881, 2006. 